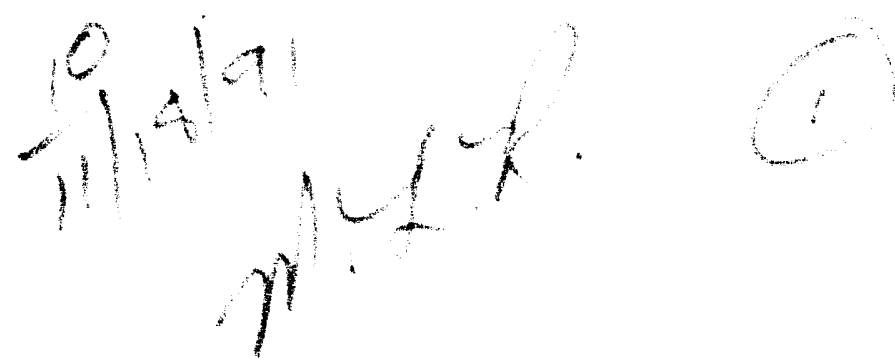

UCRL - I D - 108595

\title{
SEISMIC REFRACTION STUDIES AT THE PAINTER STREET BRIDGE SITE, RIO DELL, CALIFORNIA
}

\author{
F. E. Heuze \\ R. P. Swift
}

September, 1991

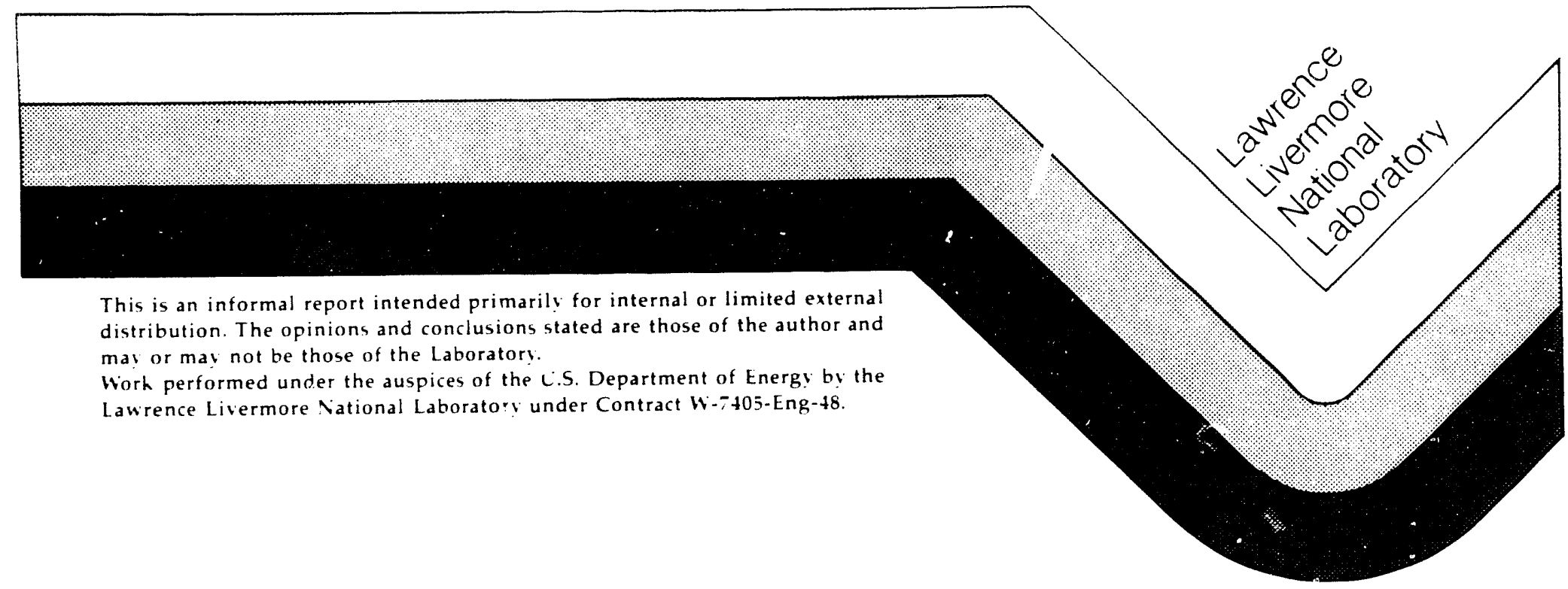




\section{DISCLAIMER}

This document was prepared as an account of work sponsored by an agency of the Linited States Government. Neither the United States Government nor the University of California nor any of their employees, makes any warranty, express or implied, or assumes any legal liability or responsibility for the accuracr, completeness, or usefulness of any information, apparatus, product, or process disclosed, or represents that its use would not infringe privately own rights. Reference herein to any specific commercial products, process, or service by trade name, trademark, manutacturer, or otherwise, does not necessarily constitute or imply its endorsement, recommendation, or favoring by the United States Government or the University of California. The views and opinions of authors expressed herein do not necessarily state or reflect those of the United States Government or the University of California, and shall not be used for advertising or producr endorsement purposes.

This report has been reproduced directly from the best available copy

Available to DOE and DOE contractors from the Office of Scientific and Technical Information

P.O. Box 62, Oak Ridge, TN 37831

Prices available from (615) $576-8401$, FTS $626-8401$

Available to the public from the

National Technical Information Service

U.S. Department of Commerce 5285 Port Royal Rd., Springfield, VA 22161 
INDEX

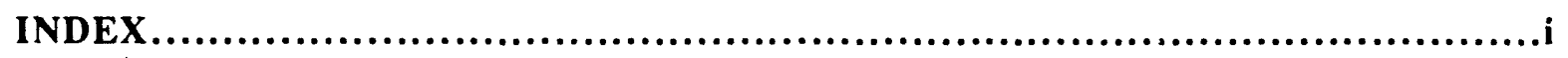

1 . OVERVIEW .............................................................. 1

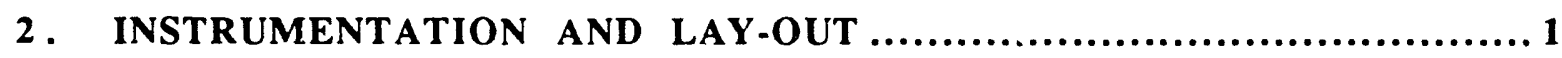

3. TEST RESULTS......................................................... 5

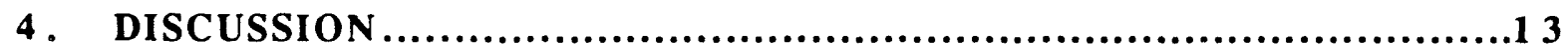

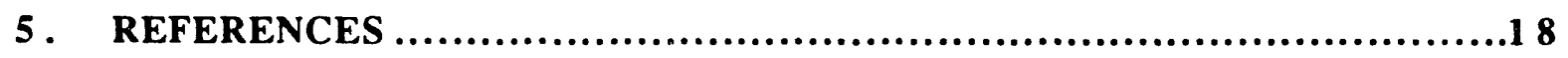

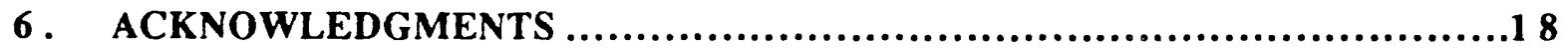

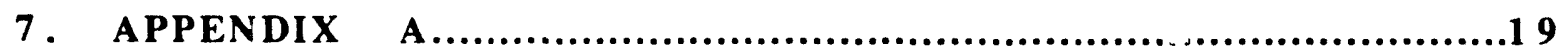

8. APPENDIX B...................................................... 3 


\section{OVERVUEW}

This report summarizes the results of seismic refraction $P$ - and S-wave measurements, at the site of the Painter Street bridge, in Rio Dell, California. The bridge is spanning highway US 101, 4 miles south of Fortuna, in northwestern California.

This study was performed to provide an estimate of niaterial properties for the foundation of the bridge, in support of a seismic stability analysis of the bridge performed at LLNL by D. McCallen. The Rio Dell region is seismically active and the Fainter Street bridge is one of only 2 bridges of its type in California, instrumented for strong motion recordings.

Figures 1 and 2 show photographs of the site, and Figure 3 shows the location of the seismic traverses. Additional overview information is given in Appendix A.

\section{INSTRUMENTATION AND LAY-OUT}

We used a 12-channel Geometric/Nimbus ES 1210 Signal Enhancement Seismograph, which can be seen on Figure $1 \mathrm{~b}$. We operated with $100-\mathrm{ft}$ long lines having $\mathrm{P}$ - and $\mathrm{S}$ - wave geophones at $10 \mathrm{ft}$ intervals. The source was a 10-lb seismic hammer striking a metal plate, for the P-waves, and hitting a $4 " \times 6 "$ timber under the front wheels of a car, for the S-waves. Typically, we recorded for $200 \mathrm{msec}$, giving $2 \mathrm{~ms}$ time intervals on the fine grid plots.

The layout of traverses shown on Figure 3, indicates a "forward" and "reverse" direction. Reverse profiling is useful when there is reason to believe that there are sloping or uneven interfaces under the ground surface.

The tests were conducted in the course of three site visits

June 26, 1991: traverses 1A and 2A F. Heuze, D. McCallen, T. Nelson

July 6-7, 1991: traverses 1B, 3, and 4 F. Heuze, R. Swift

July 15, 1991: traverse 2B F. Heuze, R. Swift

The seismograph failed on July 15, precluding additional measurements on that visit. 


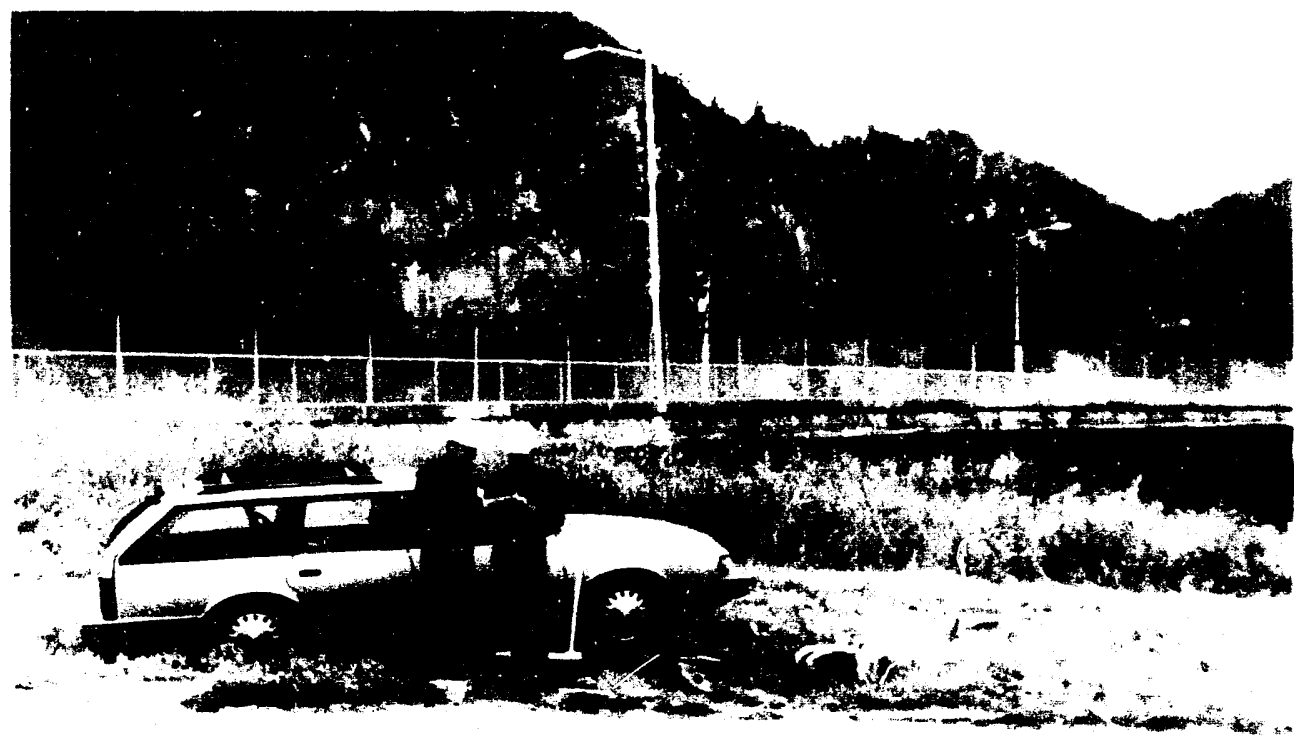

a )

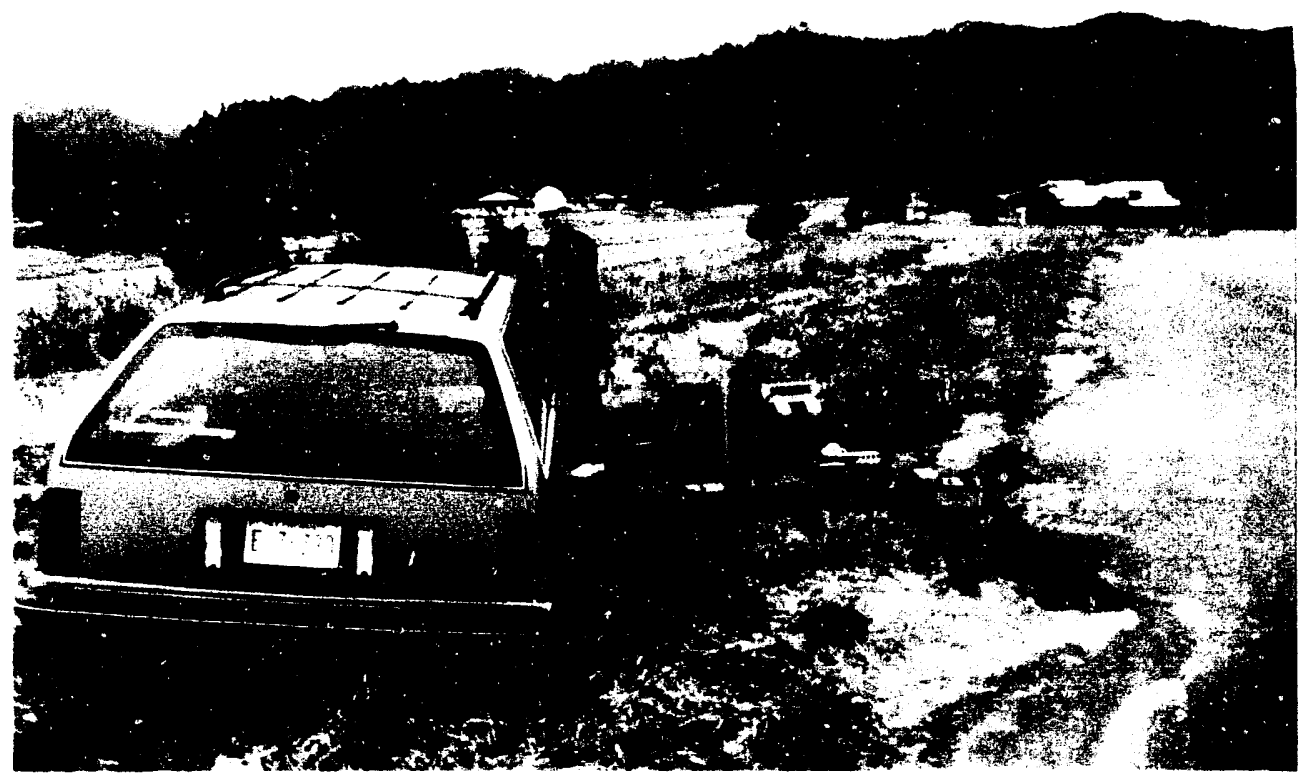

b)

Figure 1: Overview at West Ahument. Lines $1 \mathrm{~A}$ and $1 \mathrm{~B}$ 


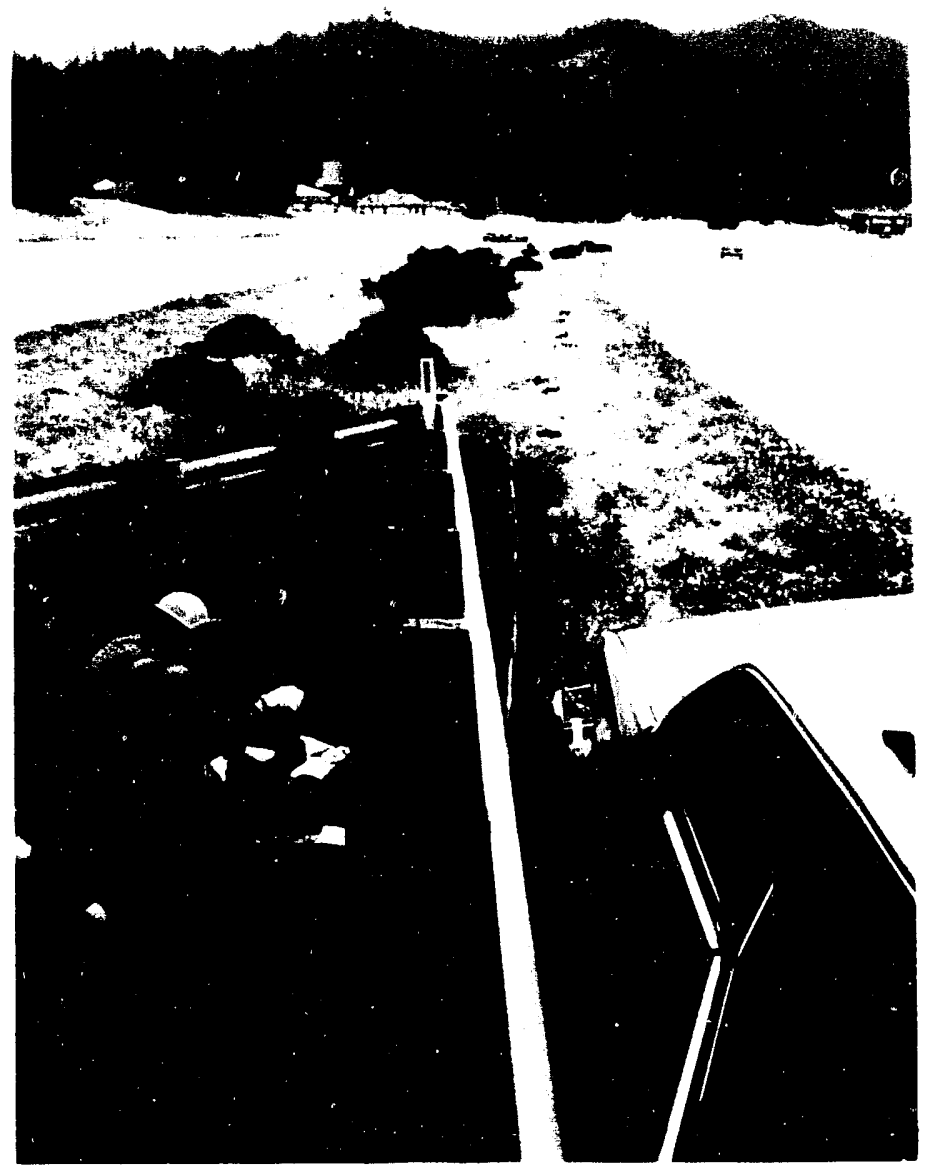

a)

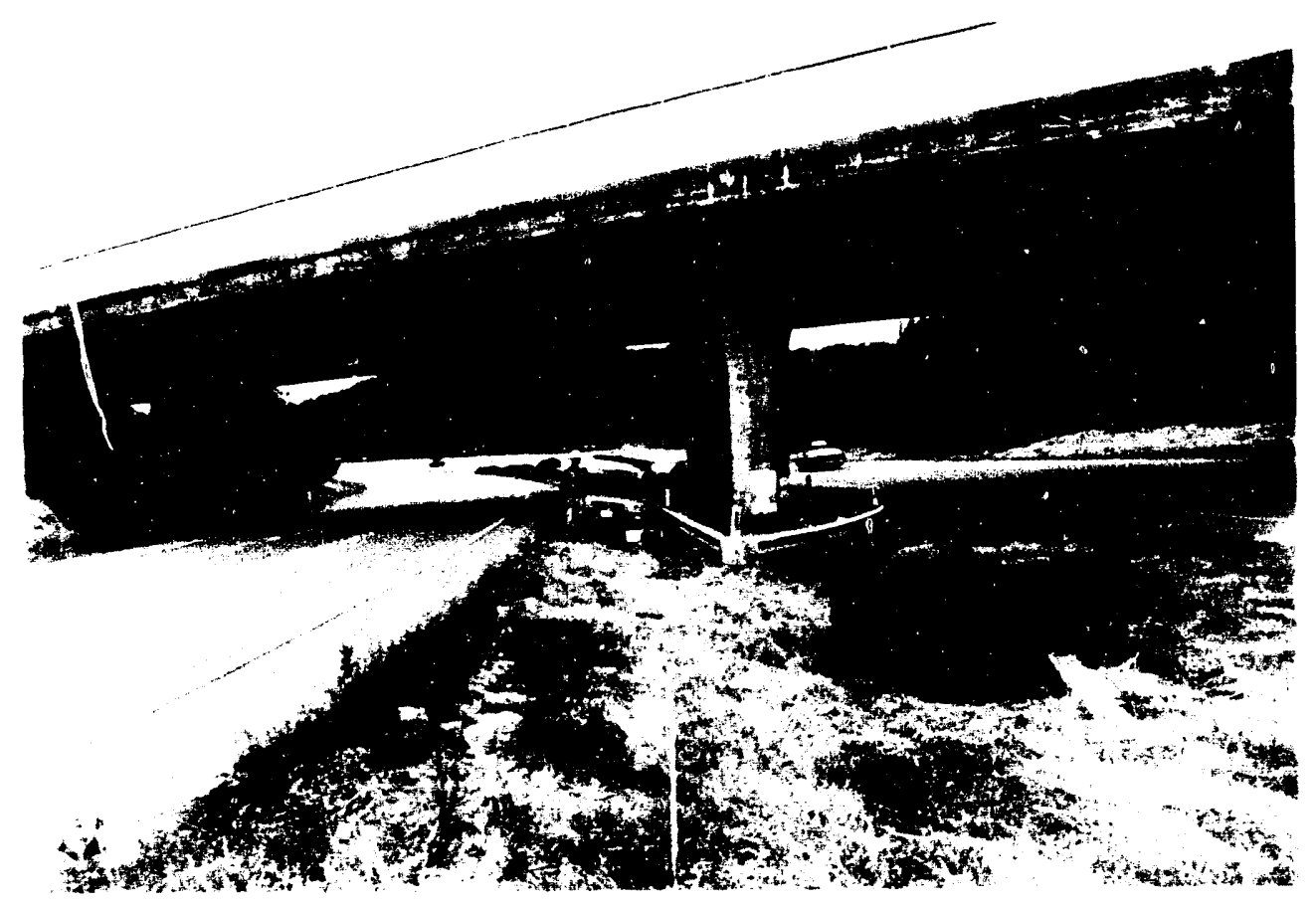

h )

Figure 2: View at Grade Level: a) Southbound b) Norbhbound 


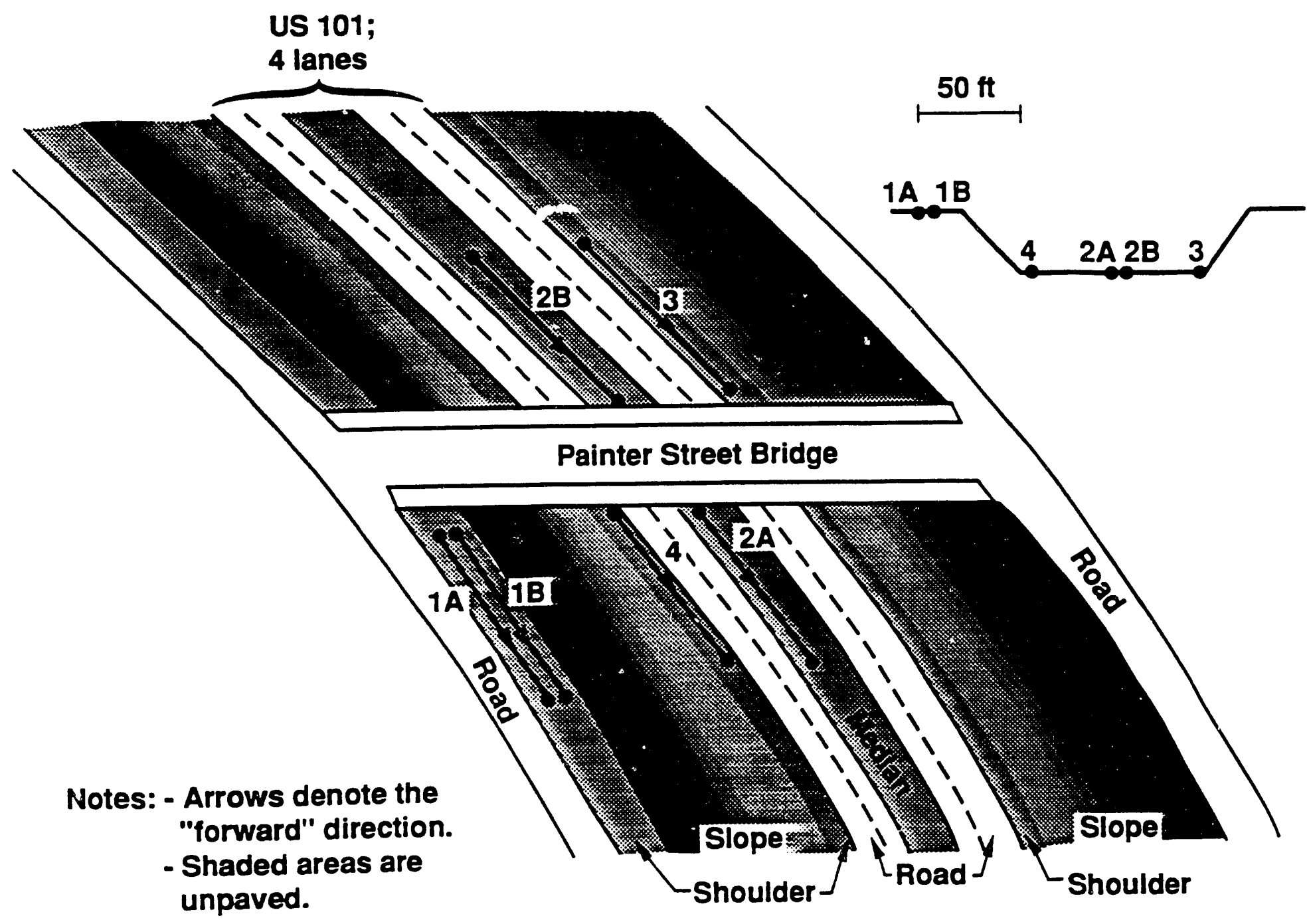

Figure 3: Lay-out of Traverses 


\section{TEST RESULTS}

Several measurements were taken along each line, for redundancy. In total, we obtained 45 such records, 24 for compression waves, and 21 for shear waves. The times of firs! arrivals are given in Appendix B.

The results are summarized in Figures 4 to 17, indicating the line number, the direction ( $F$ for forward, $R$ for reverse), the wave type ( $P$ or $S$ ), and the time of first arriva! versus distance. The labeling of symbols also indicates the repeat of a measurement. For example, 1B-P4(F) is Line 1B, fourth P-wave measurement, in the forward direction. For each line, the $P$-wave results are given first. Regression slopes indicated in the figures were done by inspection.

Based on these results, summary estimates of compression and shear wave speeds are selected as:

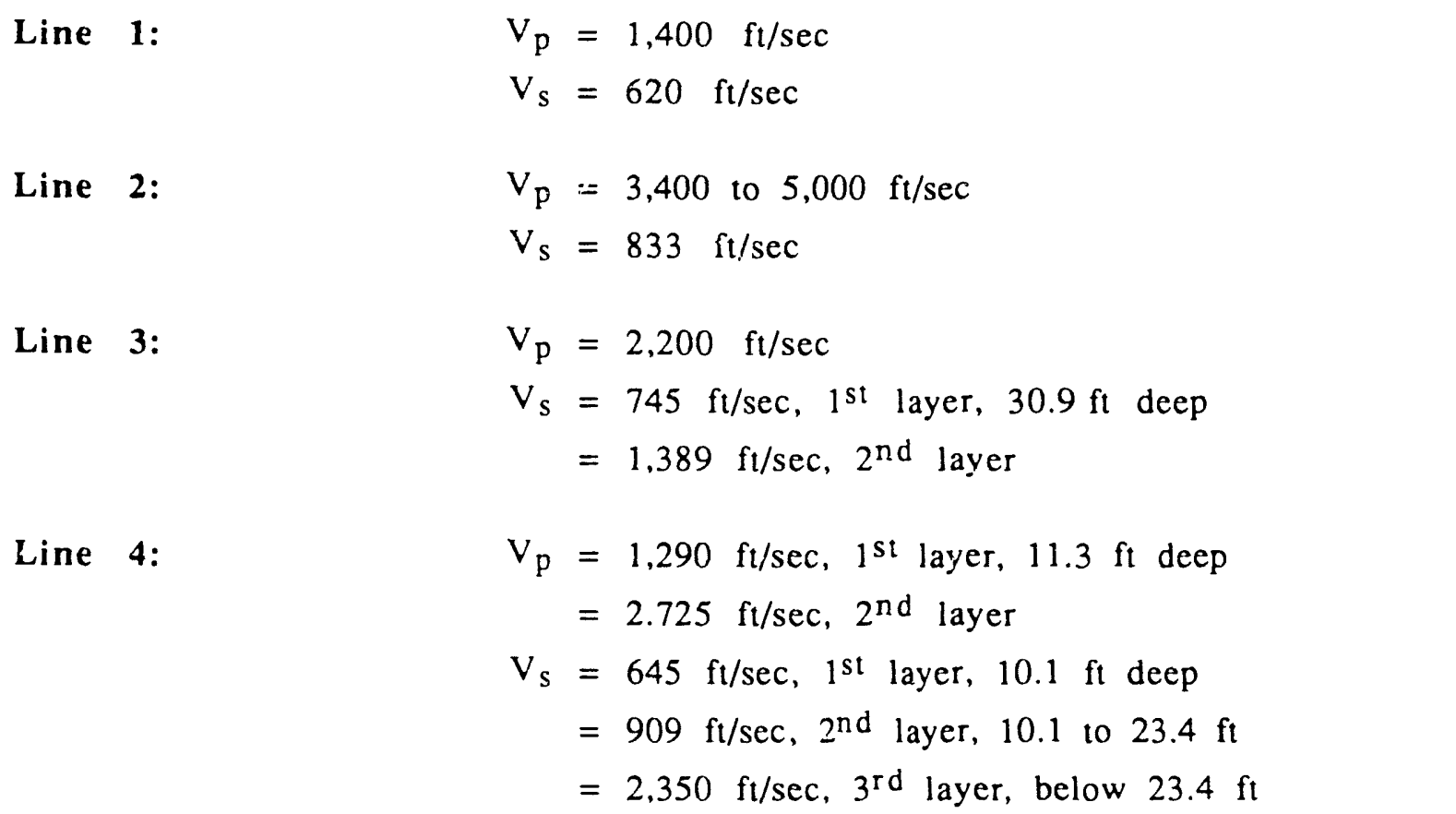

Further analysis is provided in the Discussion chapter, which follows. 


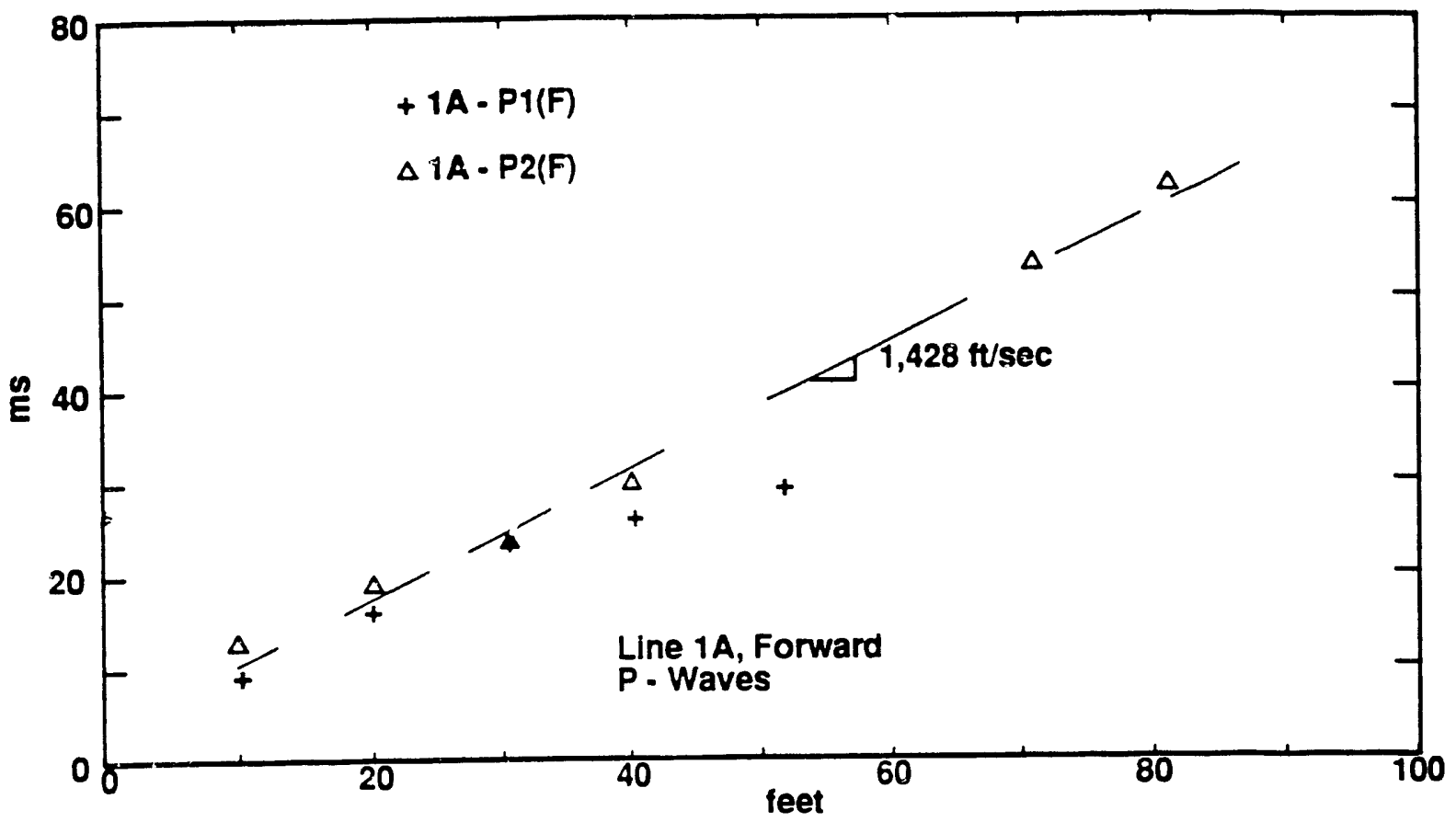

Figure 4

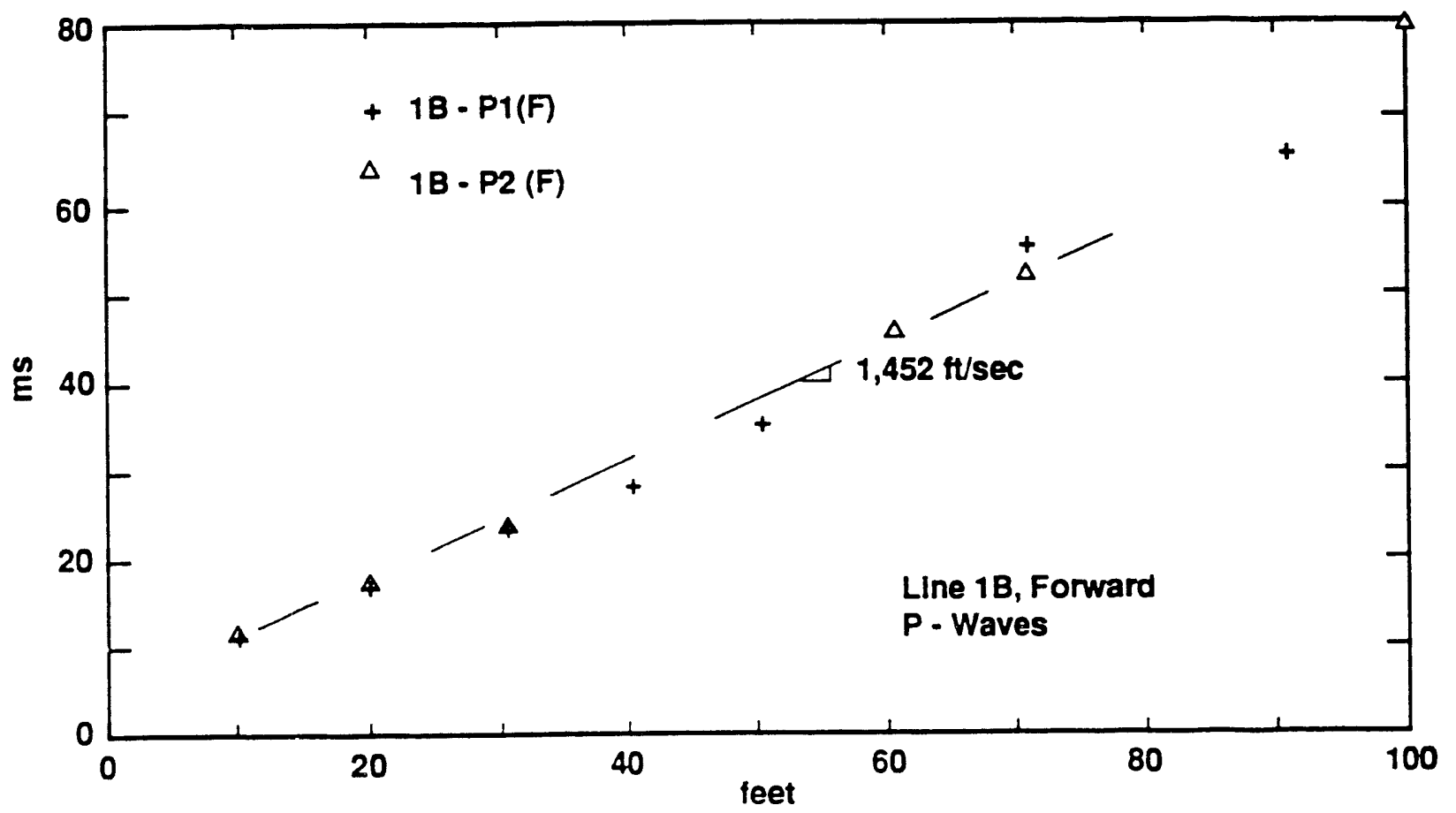

Figure 5 


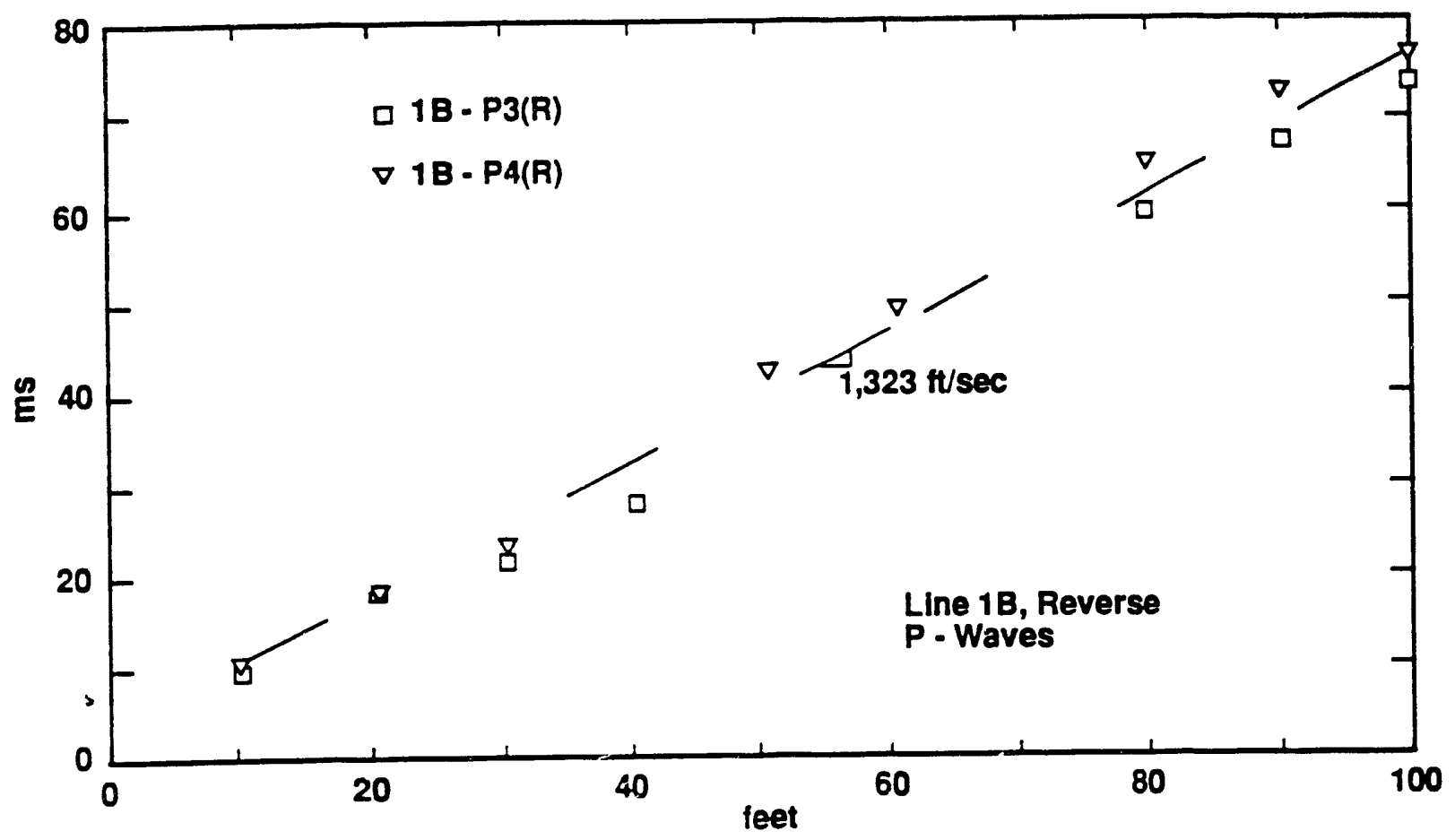

Figure 6

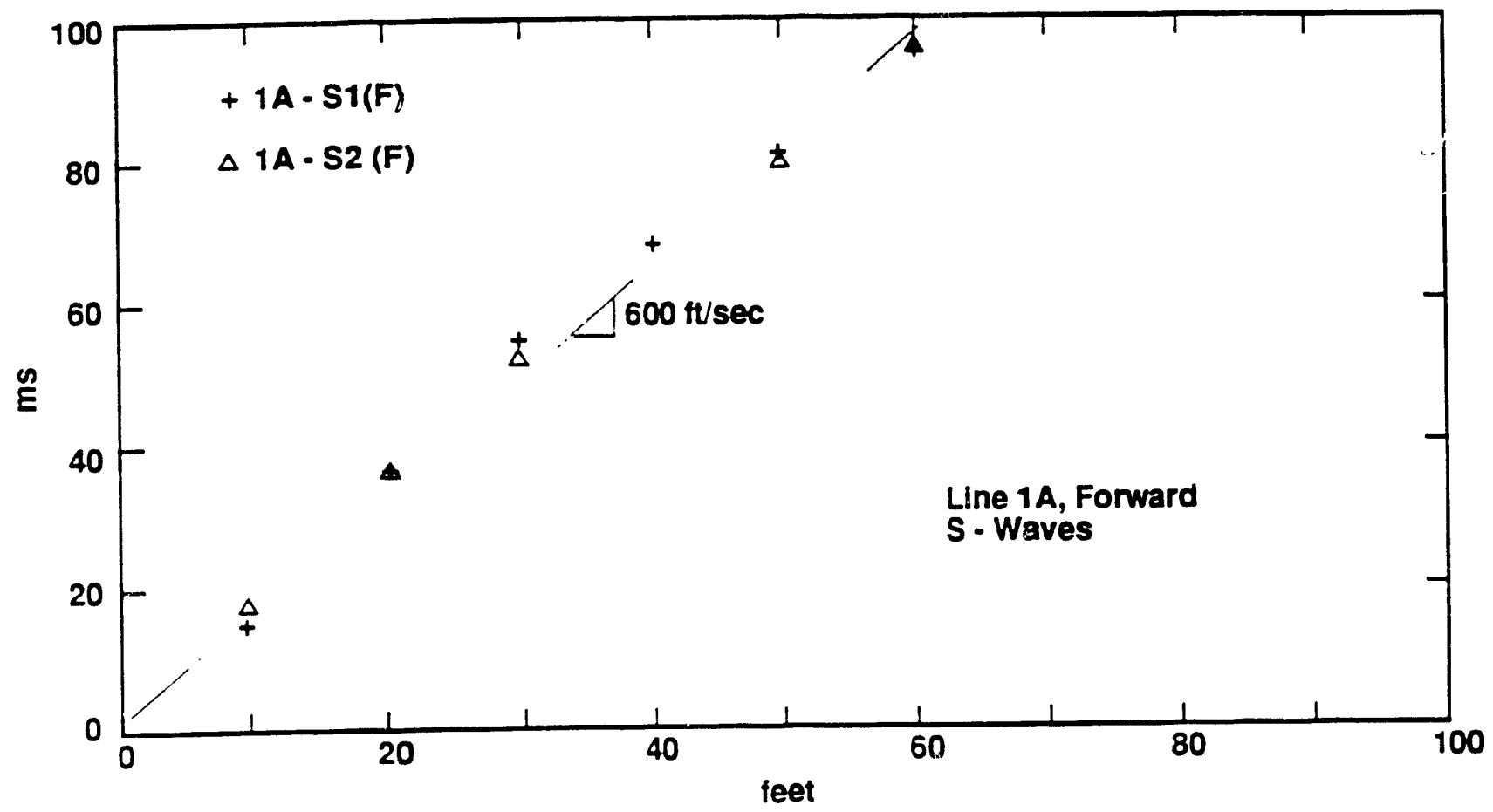

Figure 7 


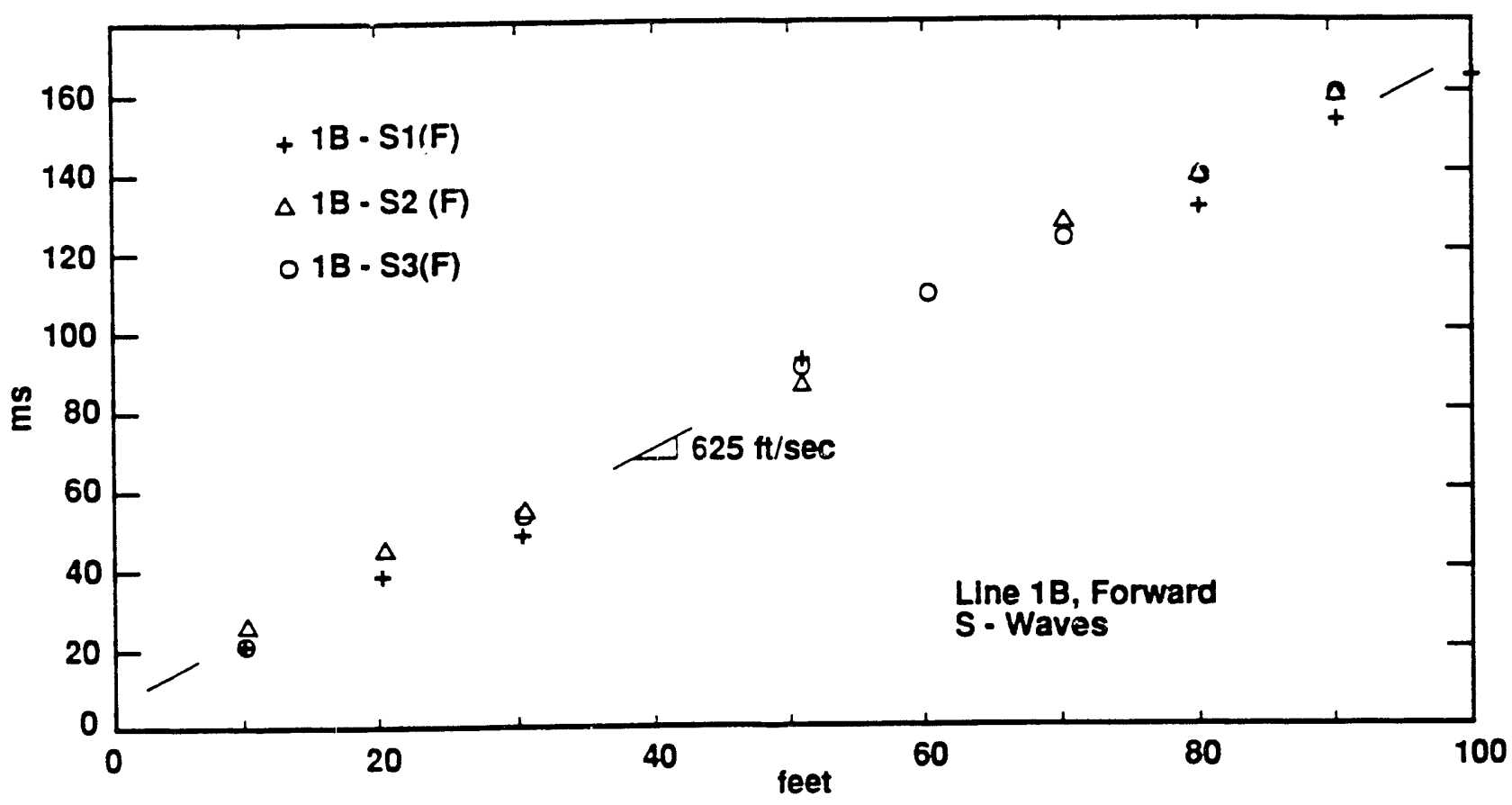

Figure 8

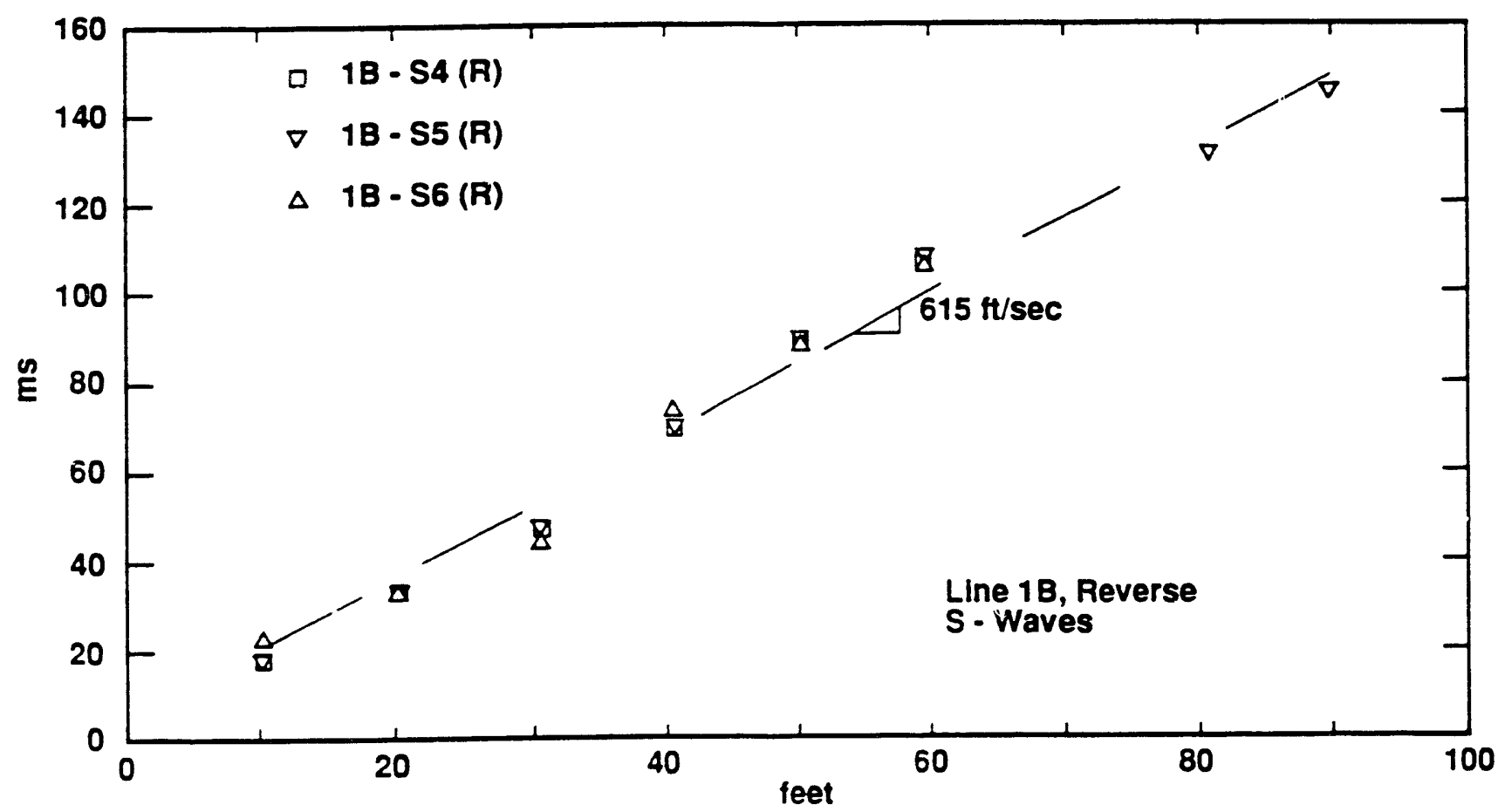

Figure 9 


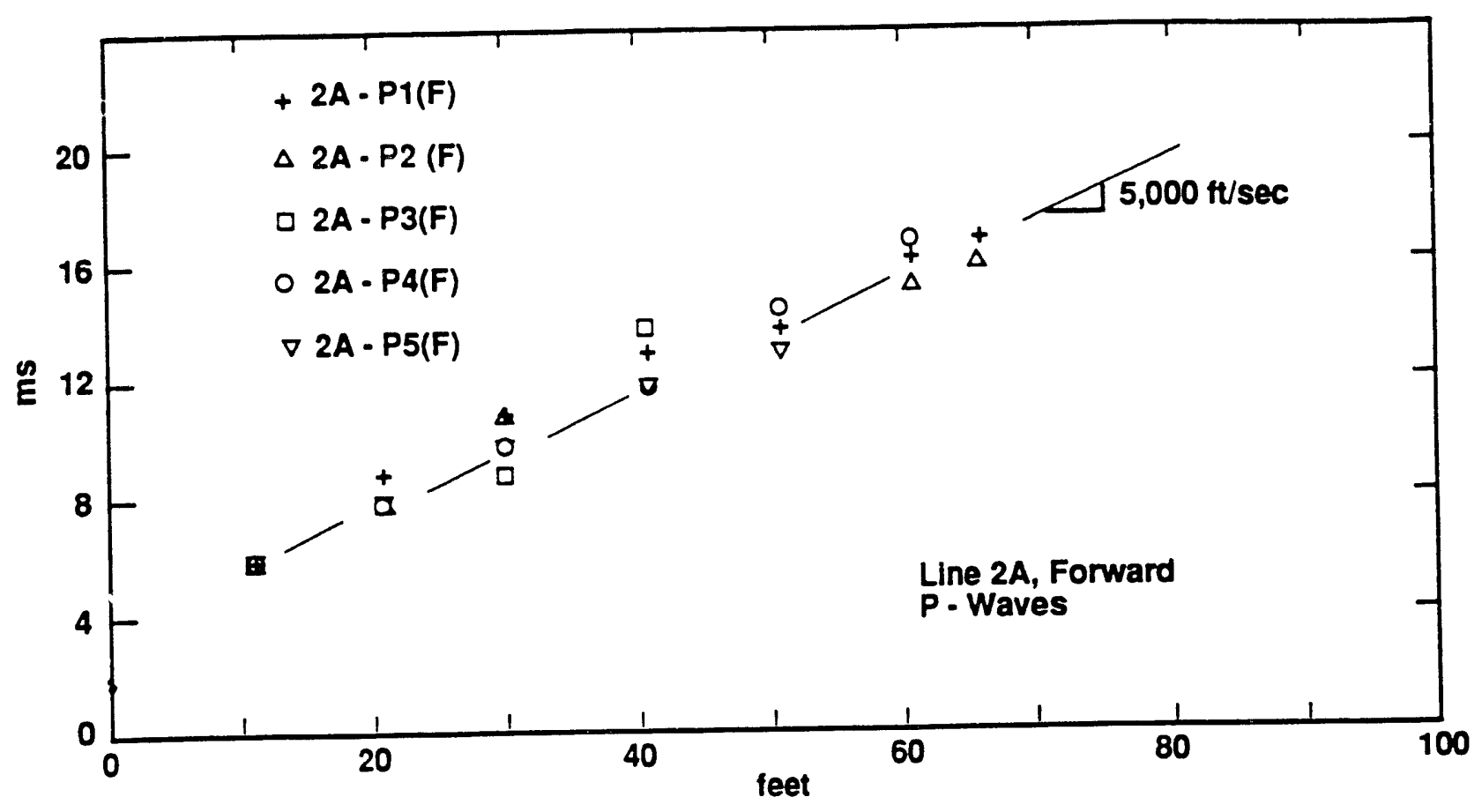

Figure 10

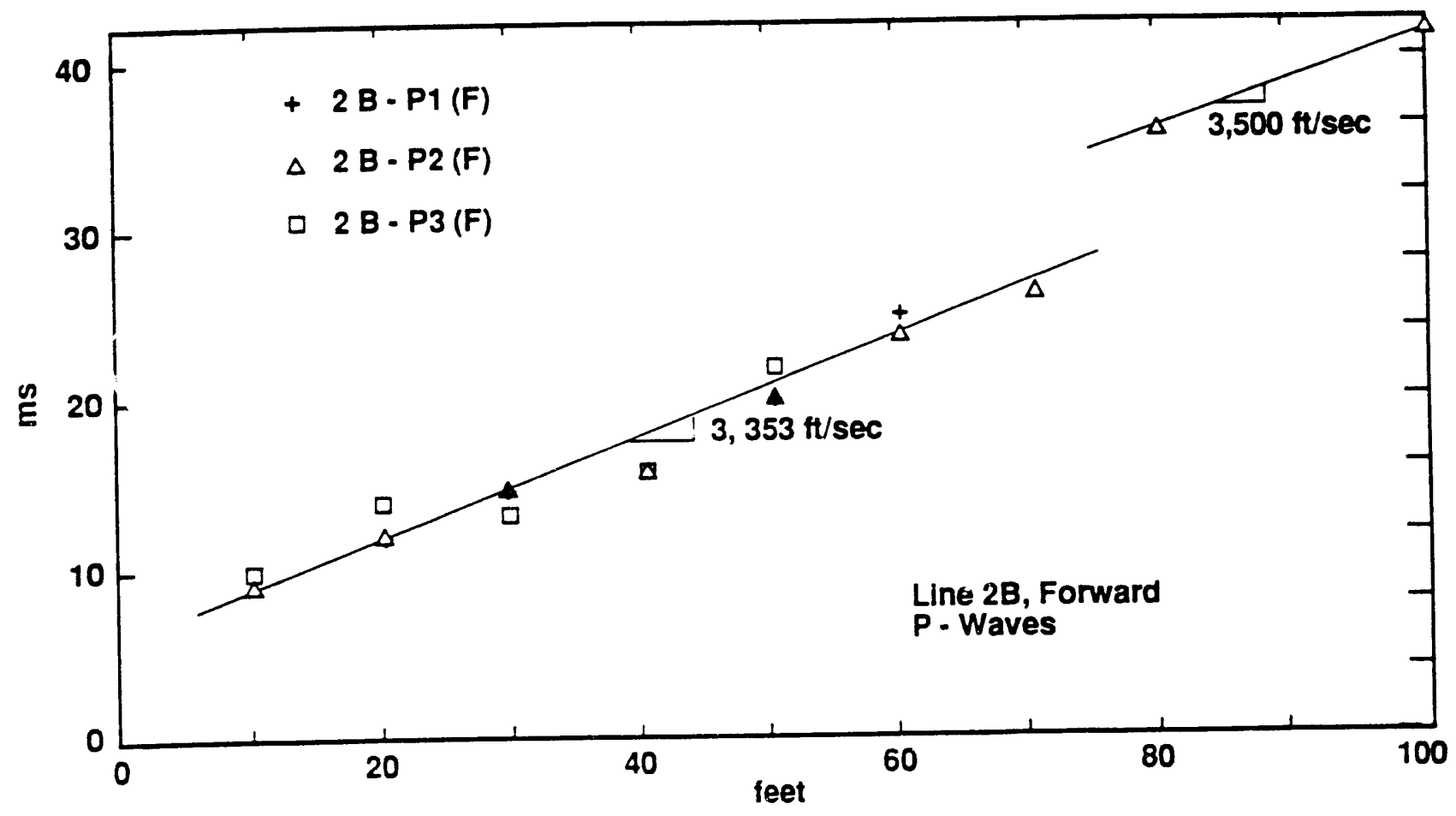

Figure 11 


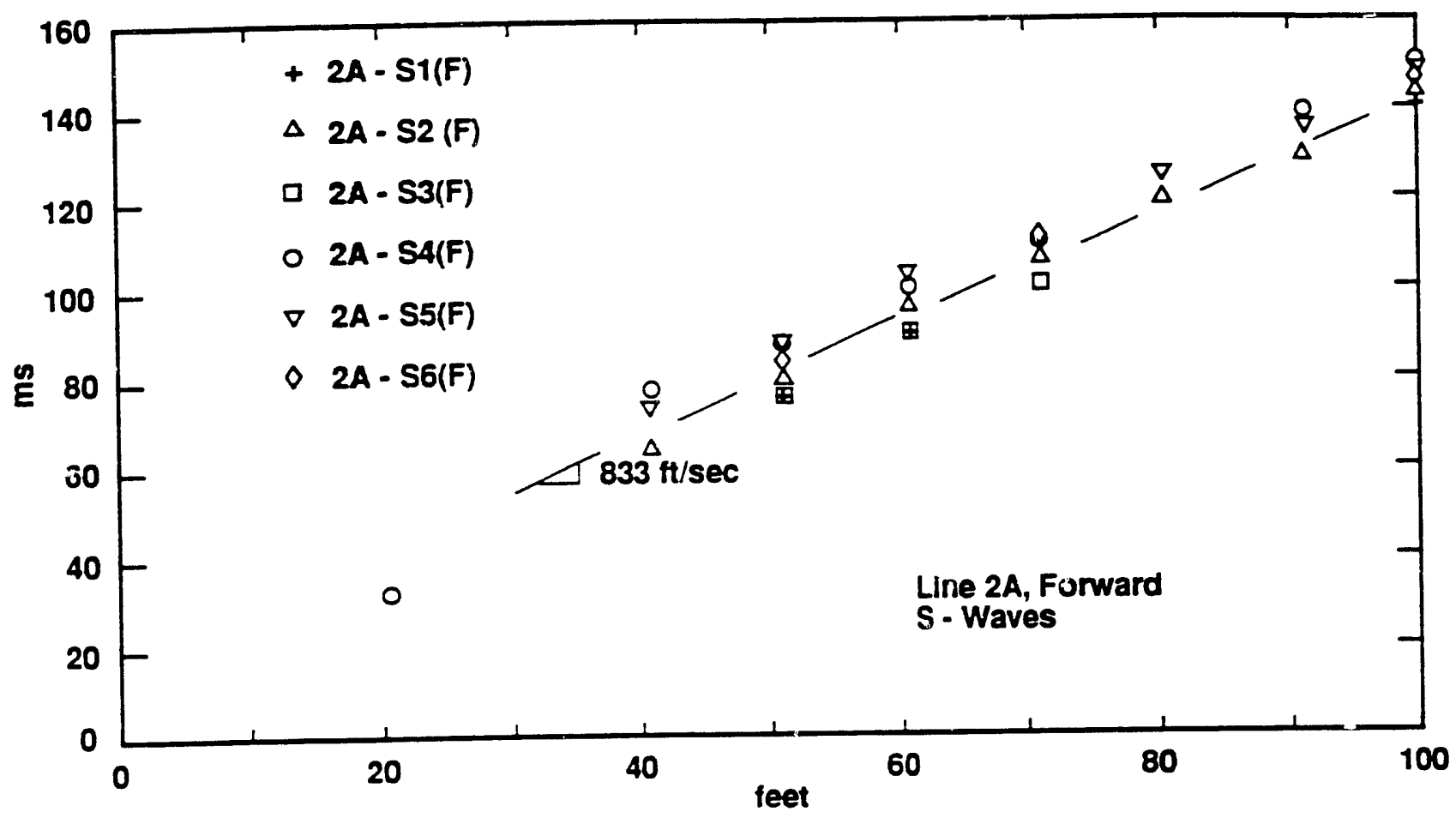

Figure 12

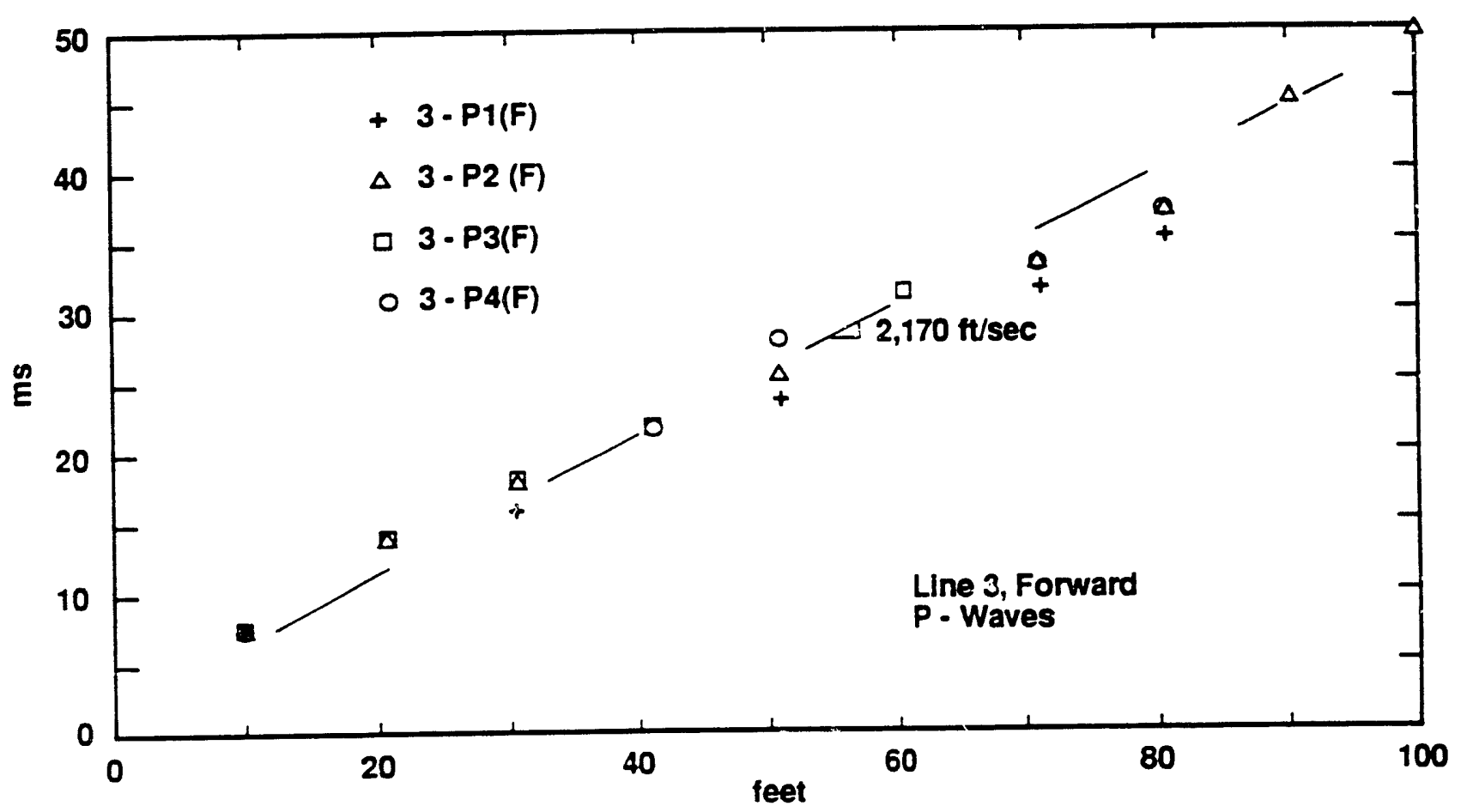

Figure 13 


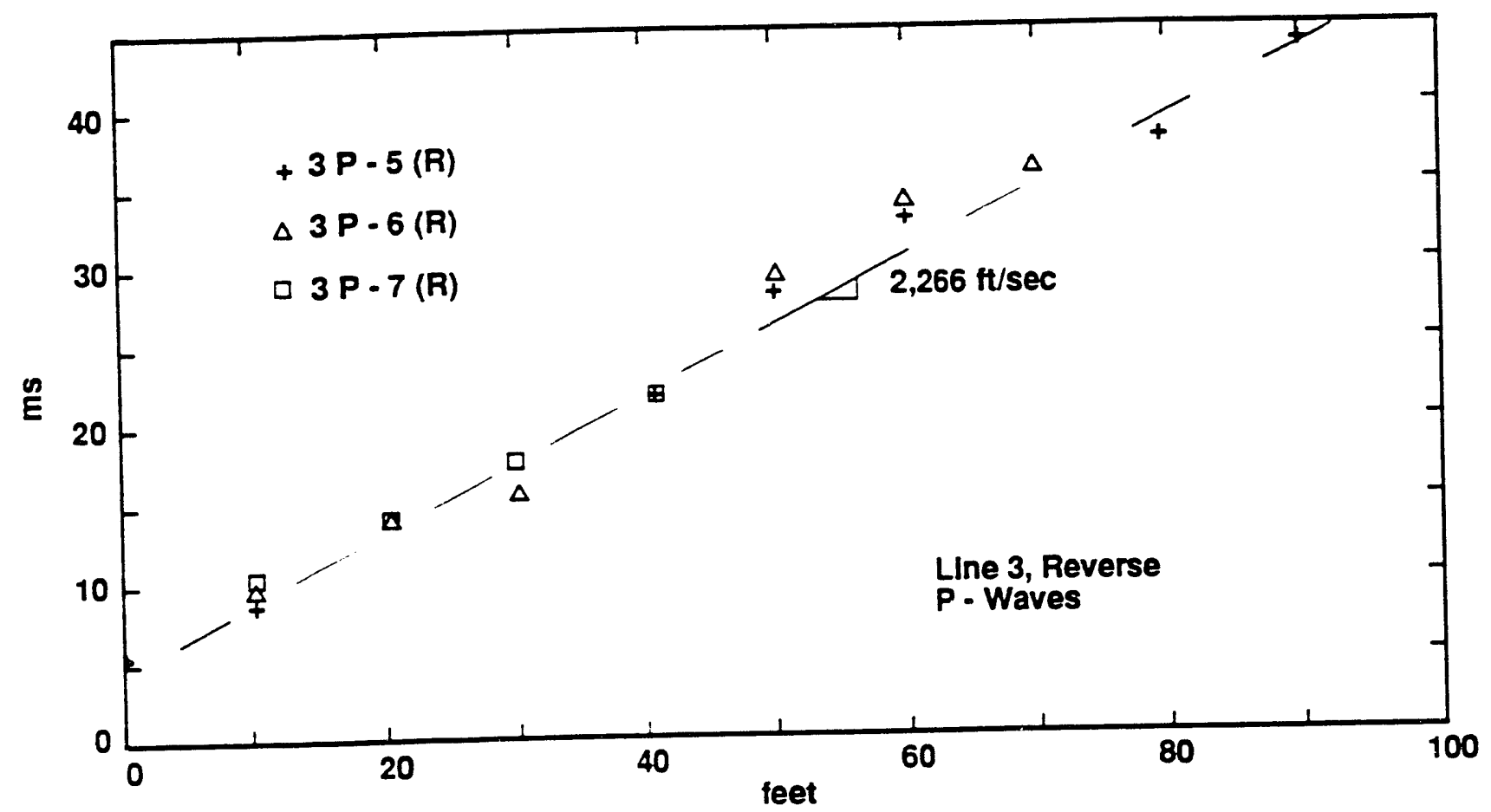

Figure 14

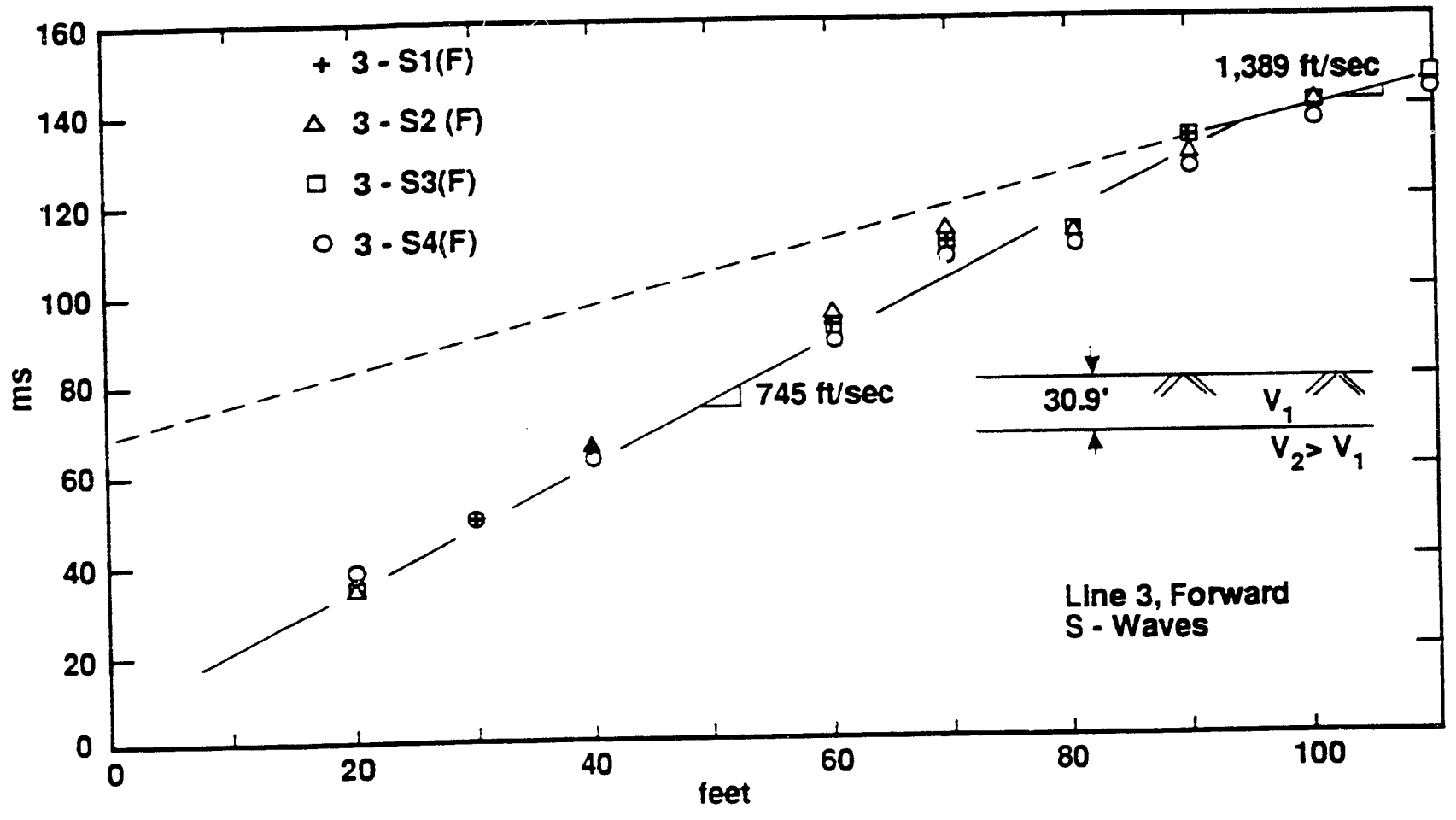

Figure 15 


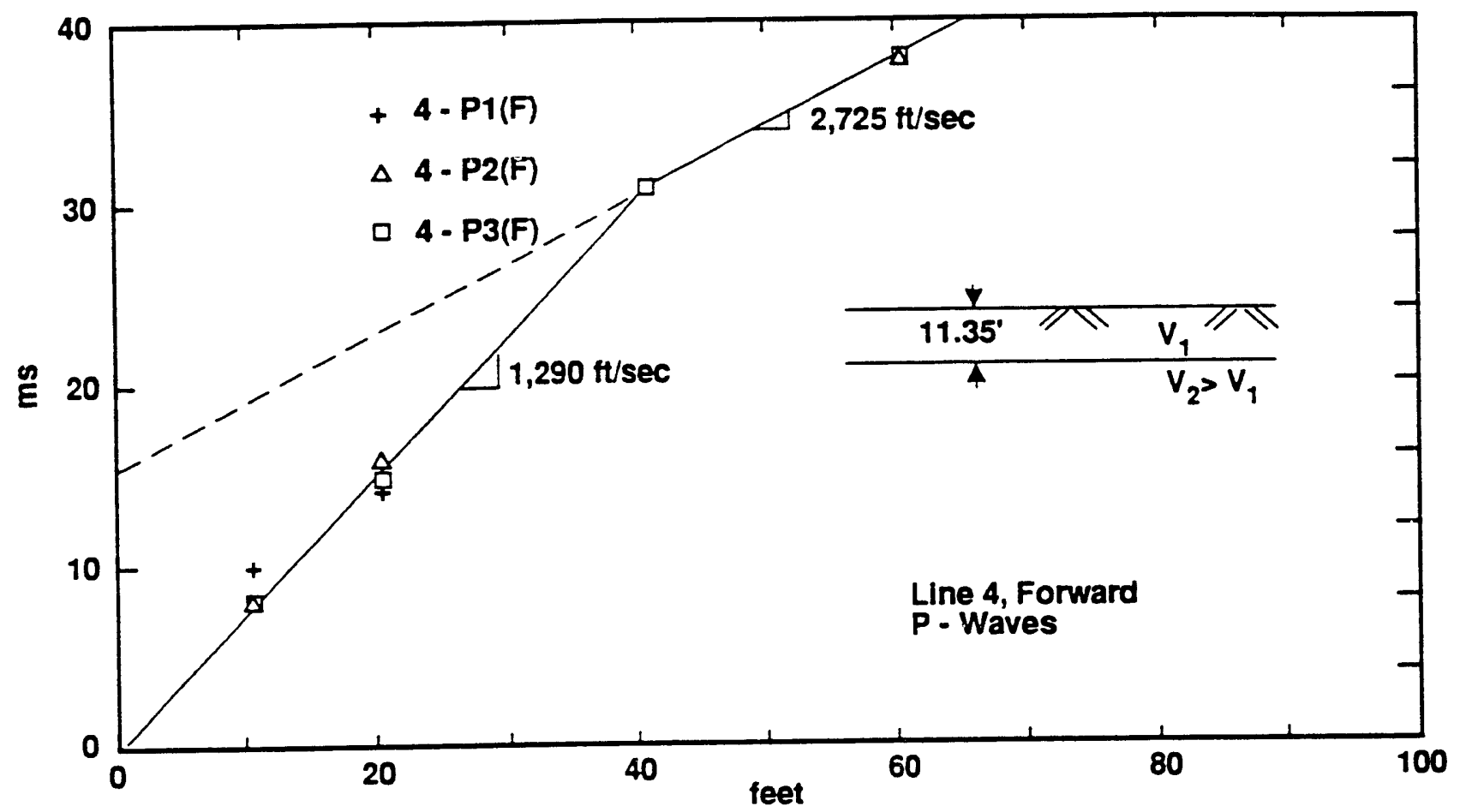

Figure 16

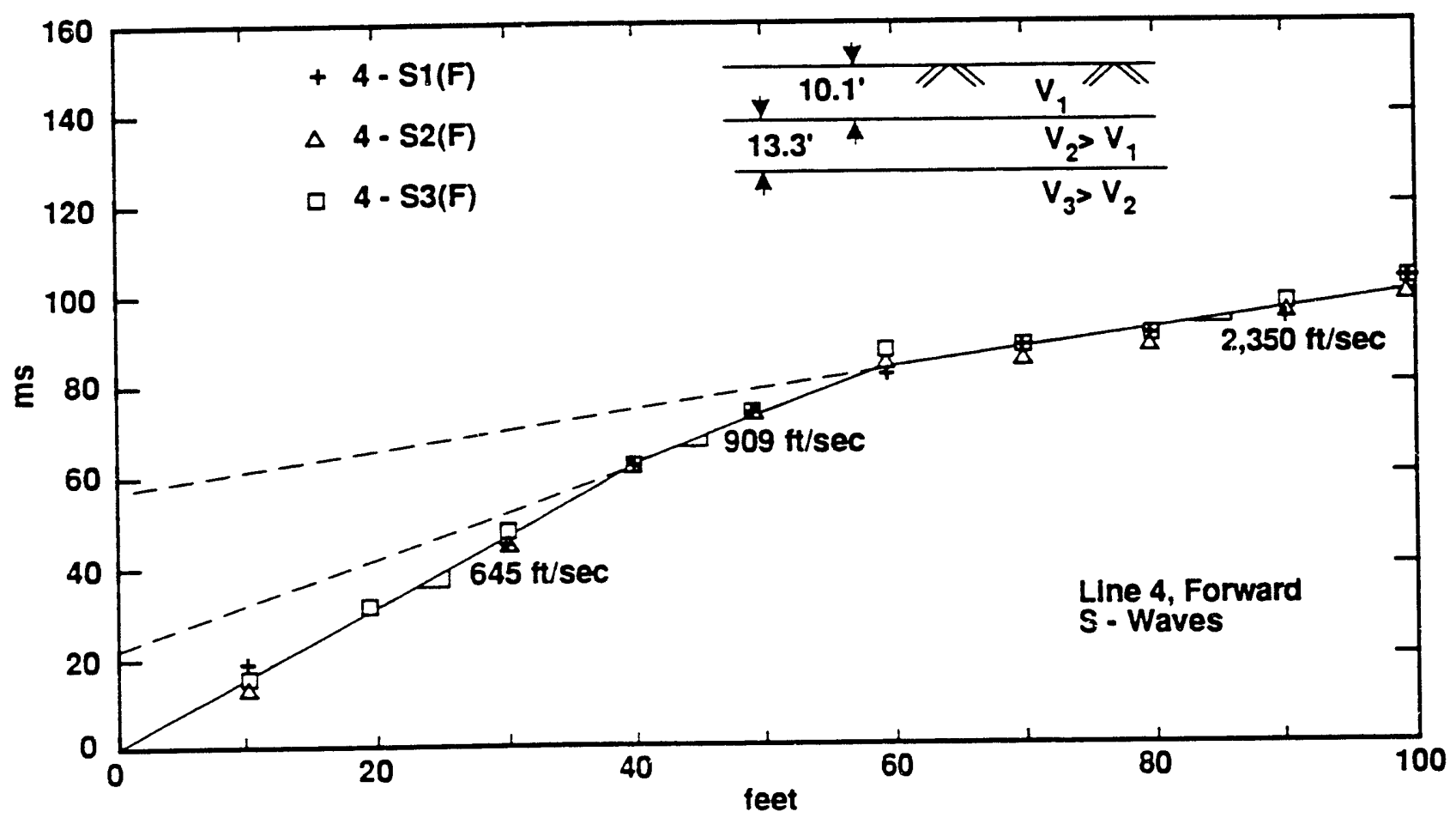

Figure 17 


\section{DISCUSSION}

The test results can be further analyzed, as follows:

- concerning $\mathrm{S}$-wave speed, which is of primary interest for the seismic analyses, there appears to be a fairly consistent range of values from around $600 \mathrm{ft} / \mathrm{s}$ on top of the east abutment to between 645 and $909 \mathrm{ft} / \mathrm{s}$ at grade level, for the first $20 \mathrm{ft}$ layer.

- the P-wave speeds, on the other hand, have a broader range. This may well be due to significant variations in moisture content. For example, the high velocity measured on line $2 \mathrm{~A}$ on June 25 could be related to the very saturated local conditions, as a sprinkler was observed to flow continuously at that location. For sands under low confining stress, the $P$-wave speed in a saturated condition can easily be 5 times higher than that in a dry state [1].

- some geologic structure can be inferred at some locations. For example, records for lines 3 and 4 show slope discontinuities, typical of layering. The estimated depths were obtained based on standard seismic refraction formulas for multiple layers [2]. The first P-wave interface could very well be the ground water surface.

- if the interface between layers is not planar and horizontal, more information on its profile can be gained by using the forward and reverse records for a single traverse, together, and calculating interface depth at the various geophone locations [3]. This can be done with the P- or Swaves. For completeness, forward and reverse plots are shown, on the same figure, for each of the three instances when both were obtained at Rio Dell: 1B-P waves, 1B-S waves, and 3-P waves. Figure 18 gathers the results from Figures 5 and 6 for P-waves from traverse 1B. Whereas wave speed estimates selected by inspection were within $10 \%$ of each other $(1,452$ and $1,323 \mathrm{ft} / \mathrm{sec})$, it appears equally plausible to show linear regressions with a slope of $1400 \mathrm{ft} / \mathrm{sec}$ for forward and reverse, on Figure 18 . So, Figure 18 does not indicate any irregular interface detected with the $100-\mathrm{ft}$ traverses. Similar conclusions can be drawn from the plots of Figure 19. It is also the case for Figure 20, where the range stops at $90 \mathrm{ft}$, and thus does not reveal the potential structure indicated in Figure 15, where a traverse was extended to $110 \mathrm{ft}$. 


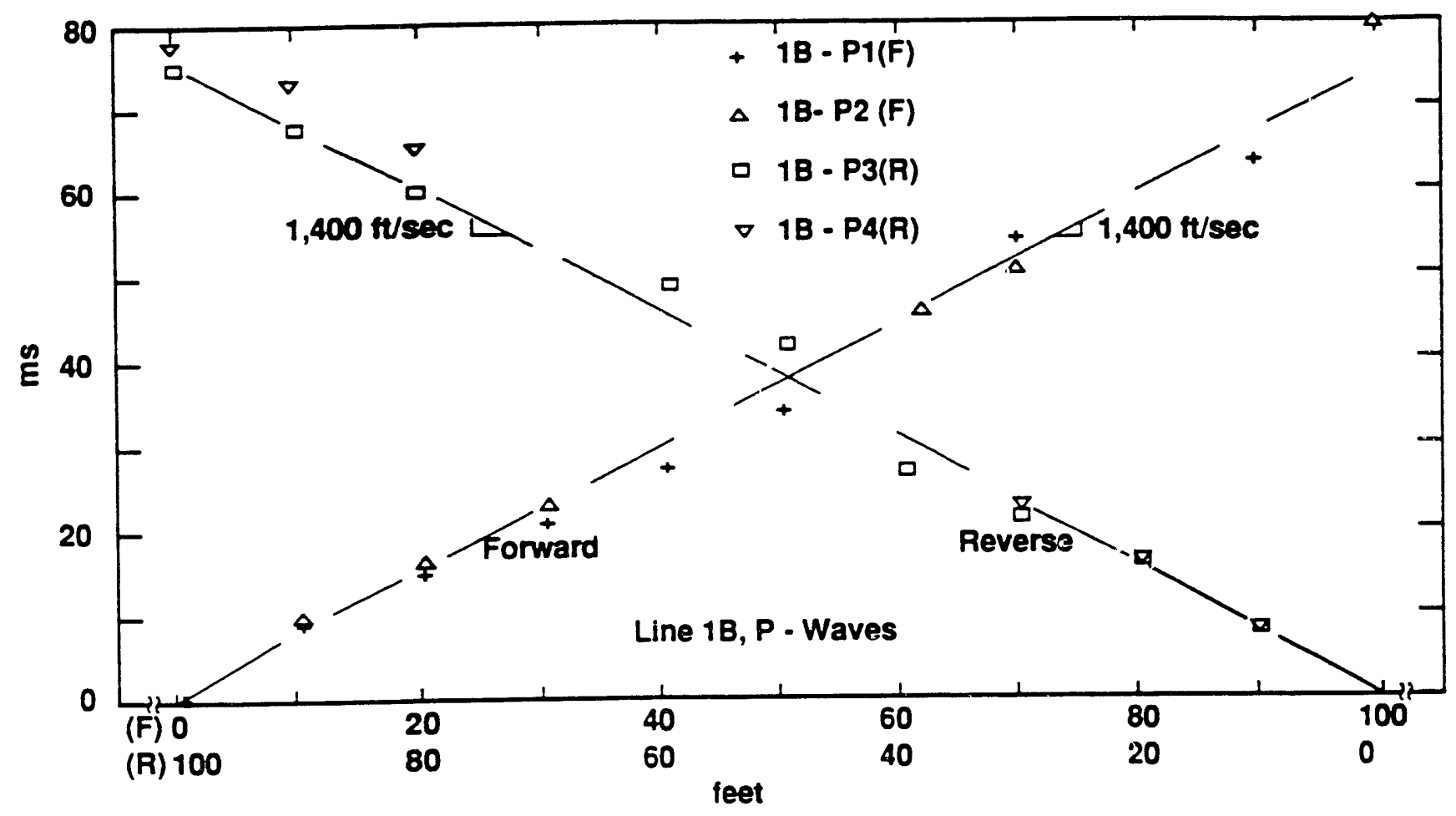

Figure 18

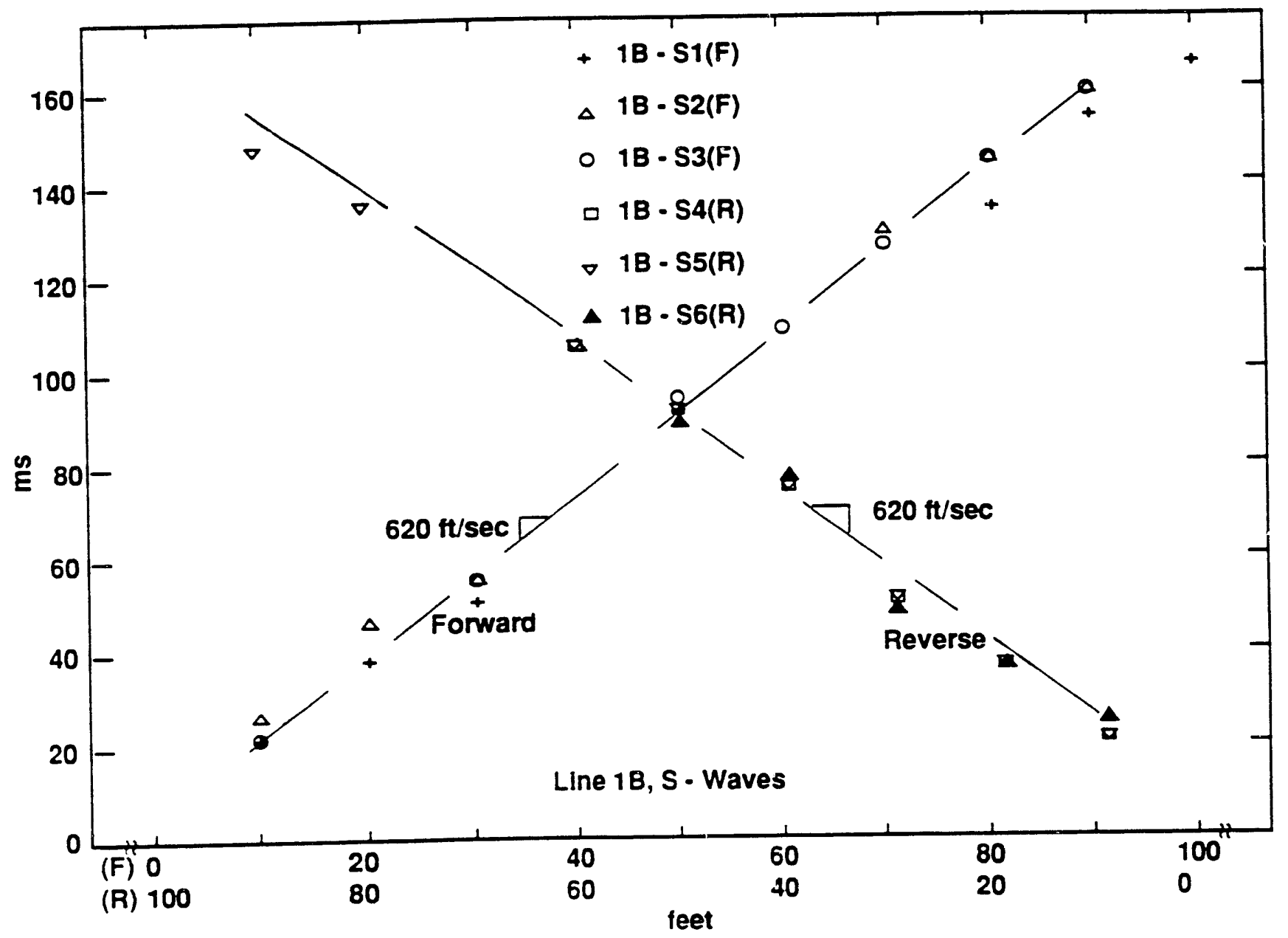

Figure 19 


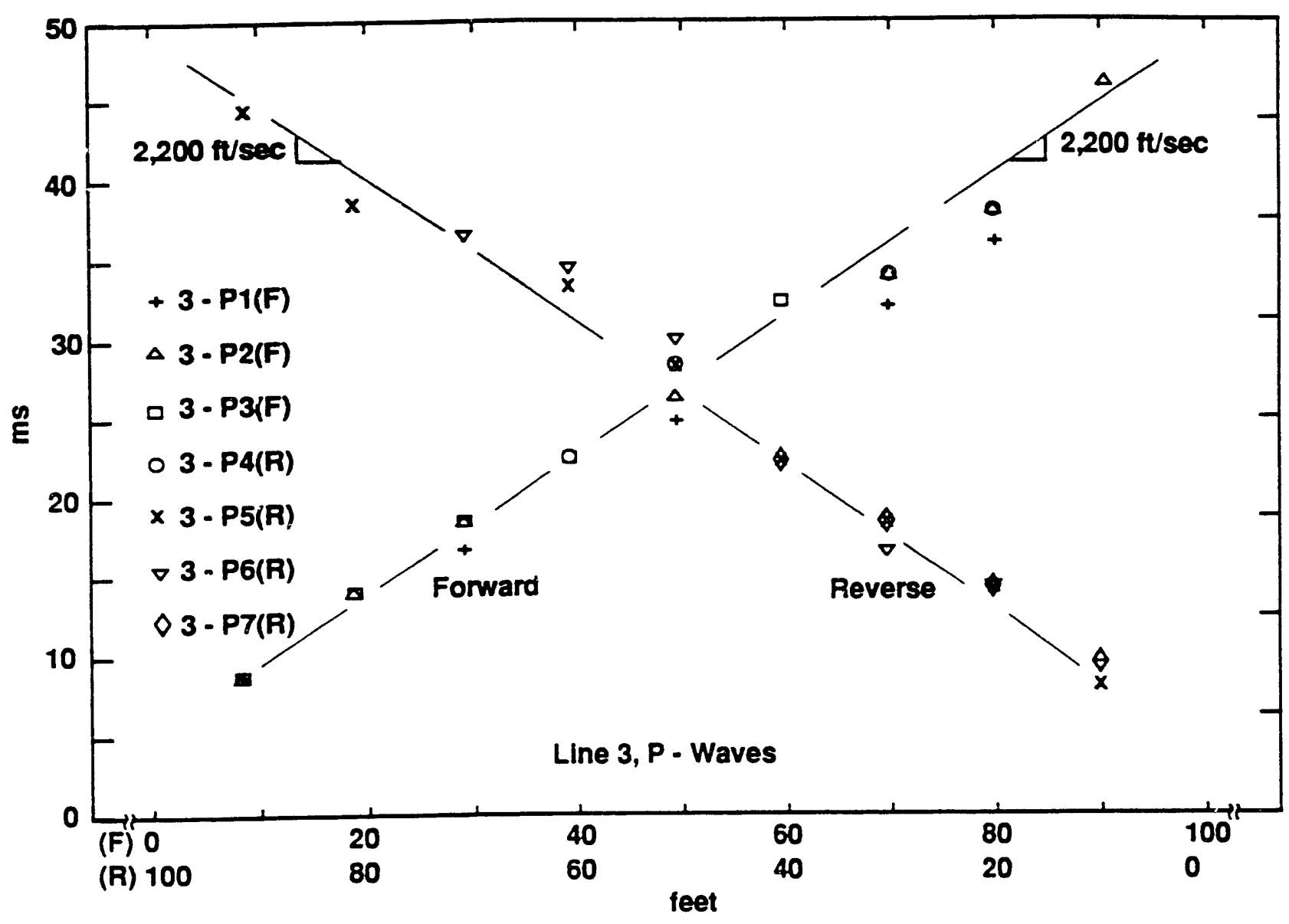

Figure 20

- estimating shear (G) and bulk (K) moduli from wave speeds requires a knowledge of material density $\rho$ which is not available from direct measurements, at this time. However, 3 borings were made before bridge construction, essentially under the center pillar and at both abutment locations. The center hole. B-2, was logged for soil type and blow count (N) from Standard Penetration Tests (SPT). This is summarized in Figure 21. Depending upon the degree of compaction, the unit weight $(\gamma)$ for a silty sand, for example, may vary between 85 and $125 \mathrm{lbs} / \mathrm{ft}^{3}$. To give a sense of the possible values for $G$ and $K$, we take an average value of density

$$
\rho=\frac{\gamma}{g}=\frac{100}{32.2} \frac{\mathrm{lbs} / \mathrm{ft}^{3}}{\mathrm{ft} / \mathrm{sec}^{2}}
$$


Elev. (feet)

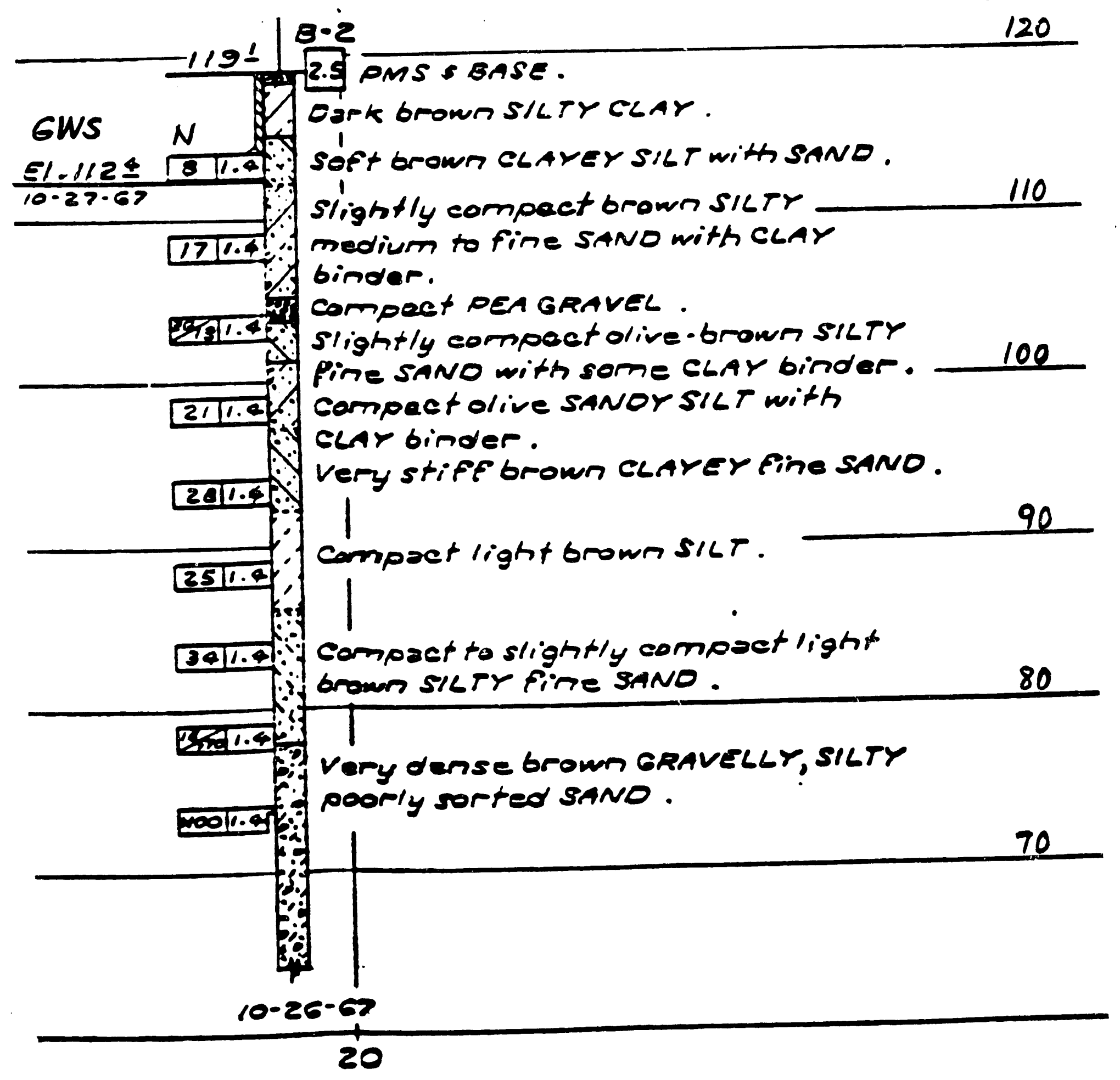

Figure 21: Log of Boring B-2, Enlarged from Figure A-3 in Appendix A. 
Now, with $G=\rho V_{s}^{2}$ and $K=\rho\left[V_{p}^{2}-\frac{4}{3} V_{s}^{2}\right]$ we estimate:

$$
\begin{aligned}
& \text { for } V_{s}=600 \mathrm{ft} / \mathrm{sec} \text { and } V_{p}=2,000 \mathrm{ft} / \mathrm{sec} \quad G=7,764 \mathrm{psi} \\
& \mathrm{K}=75,914 \text { psi } \\
& \text { for } V_{s}=900 \mathrm{ft} / \sec \text { and } V_{p}=3,000 \mathrm{ft} / \mathrm{sec} \quad G=17,469 \mathrm{psi} \\
& \mathrm{K}=170,807 \mathrm{psi}
\end{aligned}
$$

- estimating Poisson's ratio, $v$, does not require density. The equation used is

$$
v=\frac{1-2 r}{2(1-r)} \quad \text { where } \quad r=\left(\frac{V_{s}}{V_{p}}\right)^{2}
$$

Using average values, we estimate:

$$
\begin{aligned}
& \text { Line } 1 \quad V_{s}=620 \mathrm{ft} / \mathrm{sec} \quad V_{p}=1,400 \mathrm{ft} / \mathrm{s} \quad \mathrm{r}=0.196 \quad v=0.38 \\
& \text { Line } 2 \quad V_{s}=833 \mathrm{ft} / \mathrm{sec} \quad V_{p}=4,200 \mathrm{ft} / \mathrm{s} \quad \mathrm{r}=0.039 \quad v=0.48 \\
& \text { Line } 3 \quad V_{s}=745 \mathrm{ft} / \mathrm{sec} \quad V_{p}=2,200 \mathrm{ft} / \mathrm{s} \quad \mathrm{r}=0.115 \quad v=0.44 \\
& \text { Line } 4 \text { layer } 1 \quad V_{s}=645 \mathrm{ft} / \mathrm{sec} \quad V_{p}=1,290 \mathrm{ft} / \mathrm{s} \quad r=0.250 \quad v=0.33 \\
& \text { layer } 2 \quad \mathrm{~V}_{\mathrm{s}}=909 \mathrm{ft} / \mathrm{sec} \quad \mathrm{V}_{\mathrm{p}}=2,725 \mathrm{ft} / \mathrm{s} \quad \mathrm{r}=0.111 \quad \mathrm{v}=0.44
\end{aligned}
$$

- From the above information we can, in turn, estimate Young's modulus (E) values from $E=2 G(1+v)$; taking an average for $v$ as 0.40 :

$$
\begin{array}{ll}
\text { for } V_{s}=600 \mathrm{ft} / \mathrm{sec} \text { and } V_{p}=2,000 \mathrm{ft} / \mathrm{sec} & E=21,739 \mathrm{psi} \\
\text { for } V_{s}=900 \mathrm{ft} / \mathrm{sec} \text { and } V_{p}=3.000 \mathrm{ft} / \mathrm{sec} & E=48,913 \mathrm{psi}
\end{array}
$$

which are representative numbers for the soils described in the log of hole B-2 [1]. 


\section{REFERENCES}

1. Lambe, T. W., and Whitman, R. V. (1969) "Soil Mechanics", (J. Wiley and Sons, New York, NY), 553 p.

2. Mooney, H. A. (1973) "Handbook of Engineering Geophysics", (Bison Instruments Inc., Minneapolis, MN).

3. Redpath, B. B. (1973) "Seismic Refraction Exploration for Engineering Site Investigations", Lawrence Livermore National Laboratory, Technical Report E-73-4, TID-4500, May, 51p.

\section{ACKNOWLEDGMENTS}

We are grateful for the participation of David McCallen and Tom Nelson in the first field measurements, on June 26, and to Jay Zucca for the loan of the seismic equipment. We also appreciate the review comments from Richard Carlson, and the fine typing by Kathleen Kirk. 
7. APPENDIX_A

Additional information on the Painter Street Overcrossing.

Figure A-1: General Plan.

Figure A-2: $\quad$ Foundation Plan.

Figure A-3: $\quad \log$ of Test Borings. 


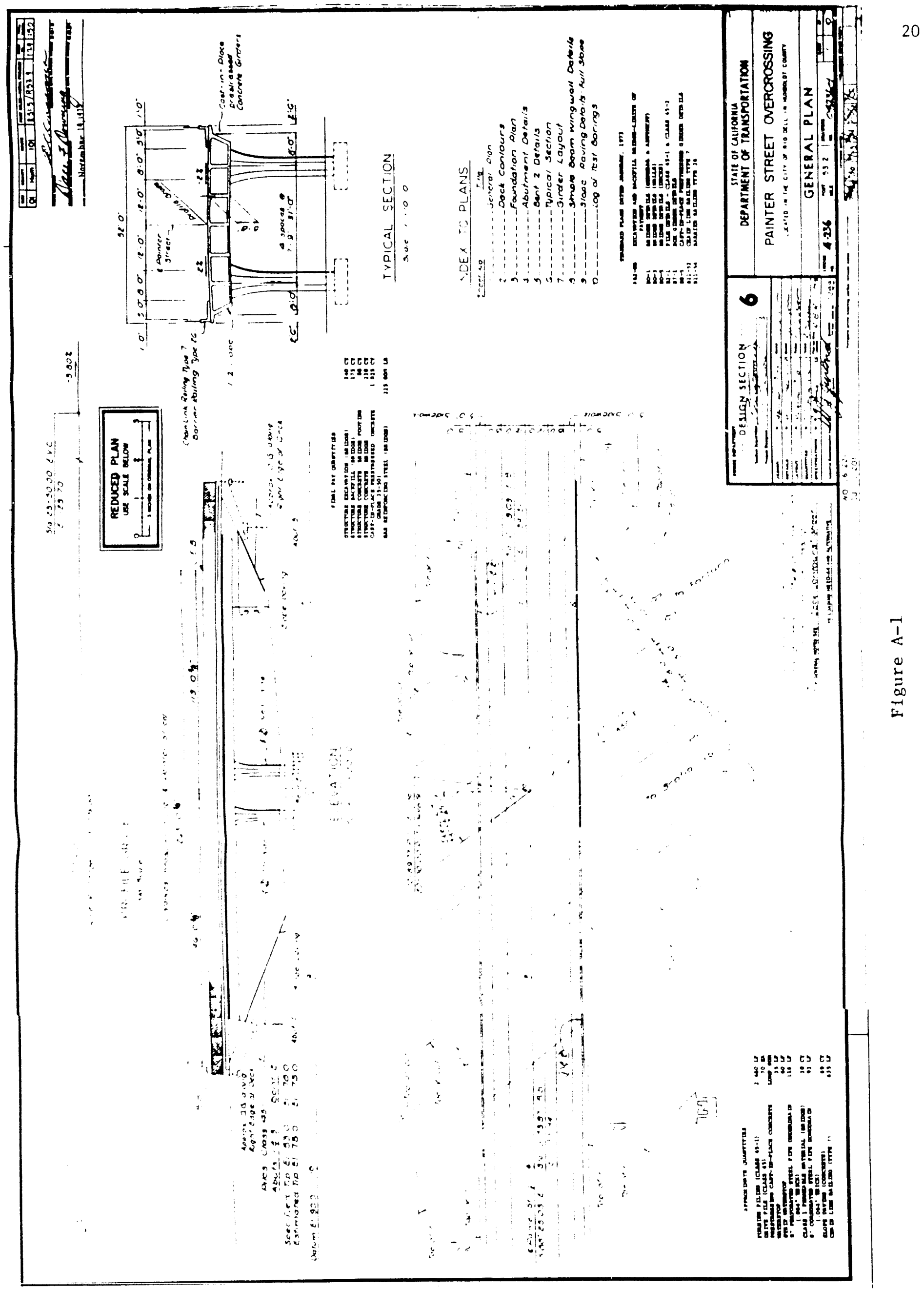




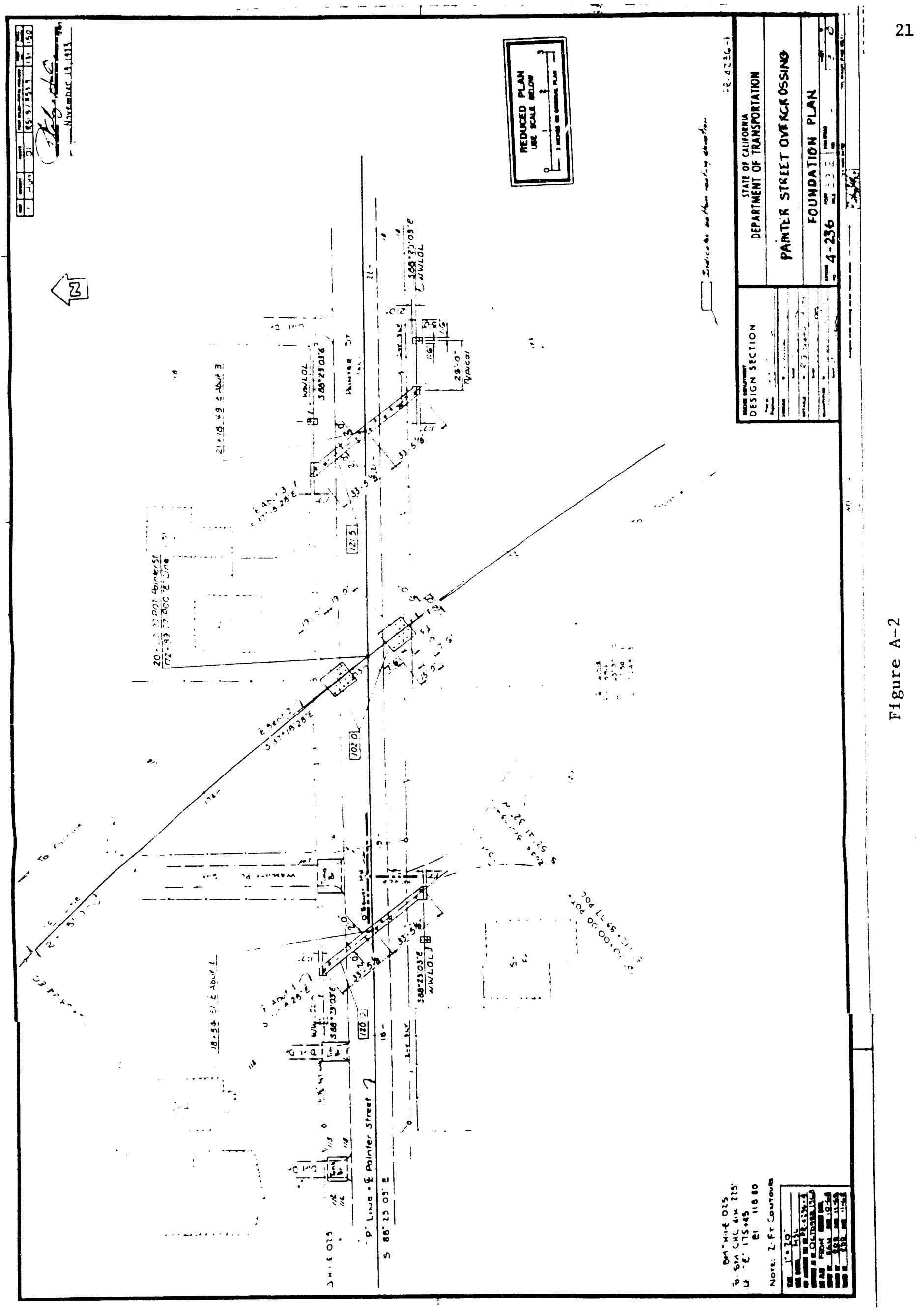




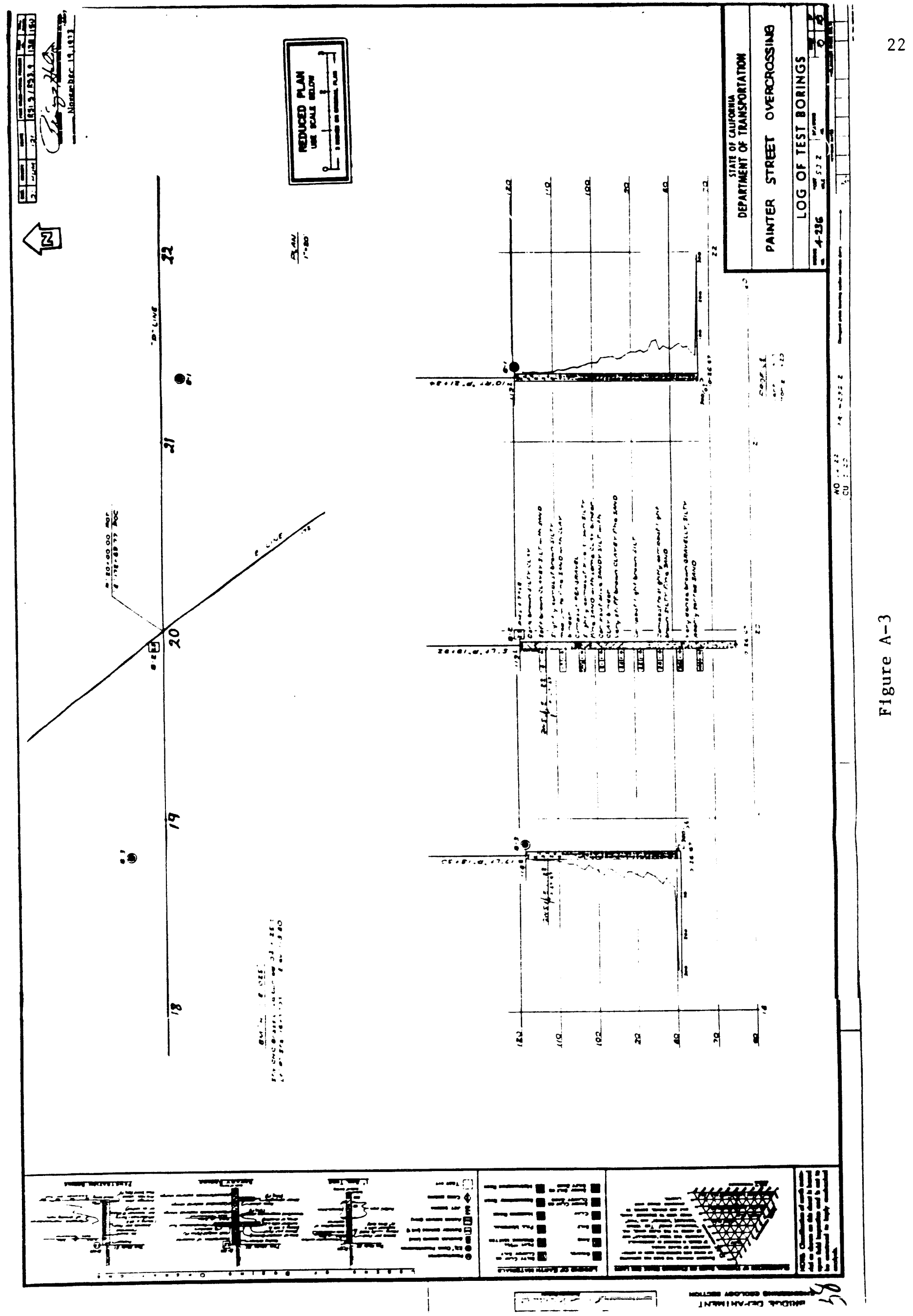


8. APPENDIX B

Times of First Arrivals (msec) From the 45 Records of Traverses $1 \mathrm{~A}, 1 \mathrm{~B}, 2 \mathrm{~A}, 2 \mathrm{~B}, 3$, and 4 
Tajle B-1: First Arrival Times (ms) of P-waves and S-waves for Six Alignments, Painter St. Bridge Site, Rio Dell, CA

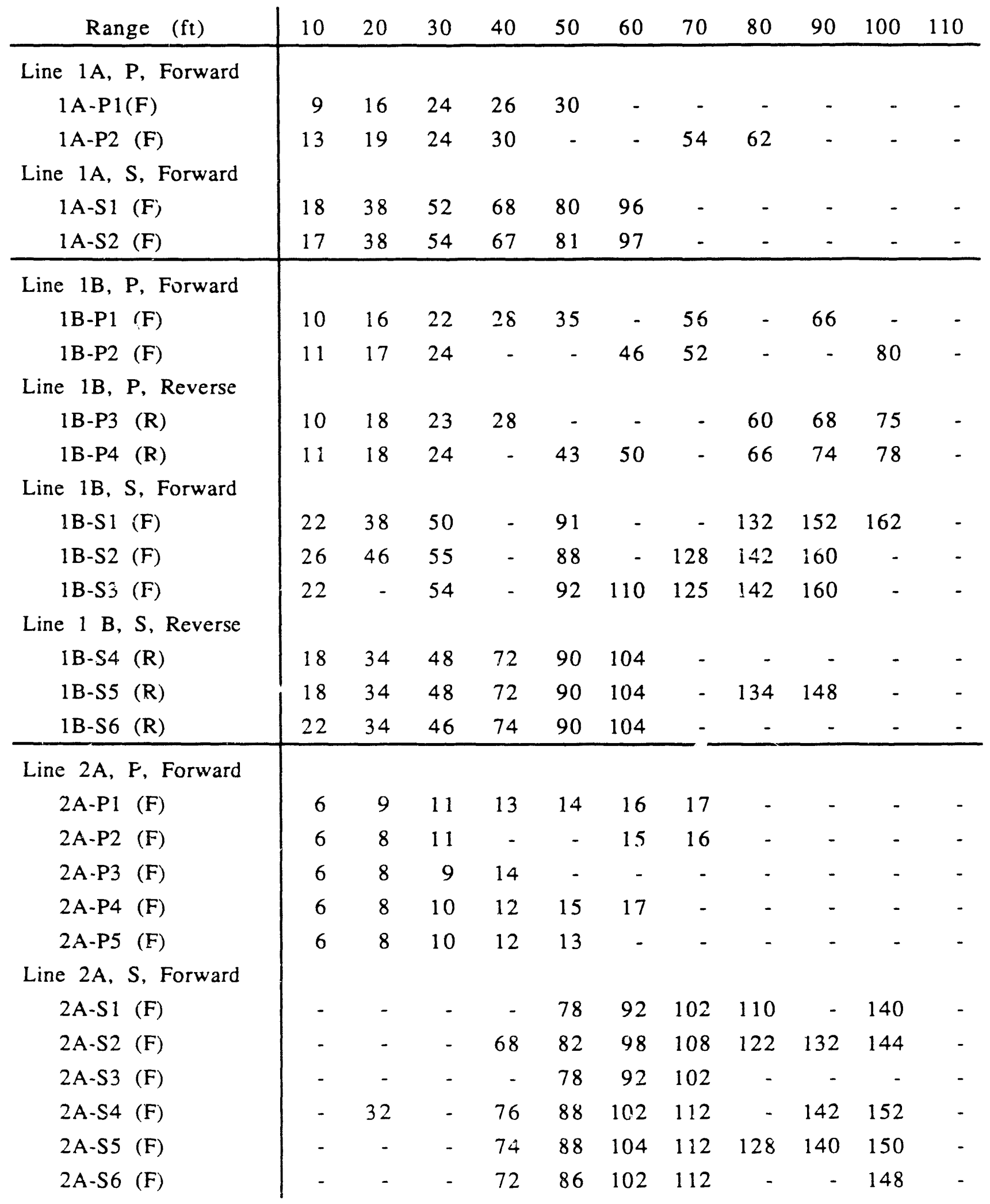




\begin{tabular}{|c|c|c|c|c|c|c|c|c|c|c|c|}
\hline Range $(\mathrm{ft})$ & 10 & 20 & 30 & 40 & 50 & 60 & 70 & 80 & 90 & 100 & 110 \\
\hline $\begin{array}{l}\text { Line } 2 \mathrm{~B}, \mathrm{P} \text {, Forward } \\
\text { 2B-P1 (F) }\end{array}$ & 10 & 12 & 15 & - & 20 & 25 & - & - & - & - & - \\
\hline 2B-P2 (F) & 9 & 12 & 15 & 16 & 20 & 24 & 26 & 36 & - & 42 & - \\
\hline 2B-P3 (F) & 10 & 14 & 14 & 16 & 22 & - & - & - & - & - & - \\
\hline Line 3, P, Forward & & & & & & & & & & & \\
\hline 3-P1 (F) & 8 & - & 16 & - & 24 & - & 32 & 36 & - & - & - \\
\hline 3-P2 (F) & 8 & 14 & 18 & - & 26 & - & 34 & 38 & 46 & & - \\
\hline 3-P3 (F) & 8 & 14 & 18 & 22 & - & - & 32 & - & - & - & - \\
\hline 3-P4 (F) & 8 & 14 & 18 & 22 & 28 & - & 34 & 38 & - & - & - \\
\hline Line $3, P$, Reverse & & & & & & & & & & & \\
\hline 3-P5 (R) & 8 & 14 & 18 & 22 & 28 & 32 & - & 38 & 44 & - & - \\
\hline 3-P6 (R) & 9 & 14 & 16 & - & 30 & 34 & 36 & - & - & - & - \\
\hline 3-P7 (R) & 10 & 14 & 18 & 22 & - & - & - & - & - & - & - \\
\hline Line 3,3 , Forward & & & & & & & & & & & \\
\hline $3-S 1 \quad(F)$ & - & 36 & 50 & 66 & - & 92 & 116 & - & 134 & 142 & 148 \\
\hline $3-S 2 \quad(F)$ & - & 36 & - & 66 & - & 94 & 112 & 114 & 132 & 142 & 148 \\
\hline $3-S 3 \quad(F)$ & - & 36 & - & - & - & 82 & 112 & 114 & 134 & 142 & 148 \\
\hline 3-S4 (F) & - & 38 & 50 & 64 & - & 89 & - & 112 & 130 & 140 & 146 \\
\hline Line $4, \mathrm{P}$, Forward & & & & & & & & & & & \\
\hline 4-P1 (F) & 10 & 14 & - & - & - & - & 42 & - & - & - & - \\
\hline 4-P2 (F) & 8 & 16 & - & - & - & 38 & - & - & - & - & - \\
\hline 4-P3 (F) & 8 & 15 & - & 31 & - & 38 & - & - & - & - & - \\
\hline Line $4, \mathrm{~S}$, Forward & & & & & & & & & & & \\
\hline 4-S1 (F) & 16 & - & 46 & 62 & 72 & 82 & 88 & 92 & 96 & 102 & - \\
\hline 4-S2 (F) & 12 & - & 46 & 62 & 72 & 84 & 86 & 90 & 96 & 100 & - \\
\hline $4-S 3 \quad(F)$ & 14 & 30 & 48 & 62 & 72 & 86 & 88 & 92 & 98 & 102 & - \\
\hline
\end{tabular}



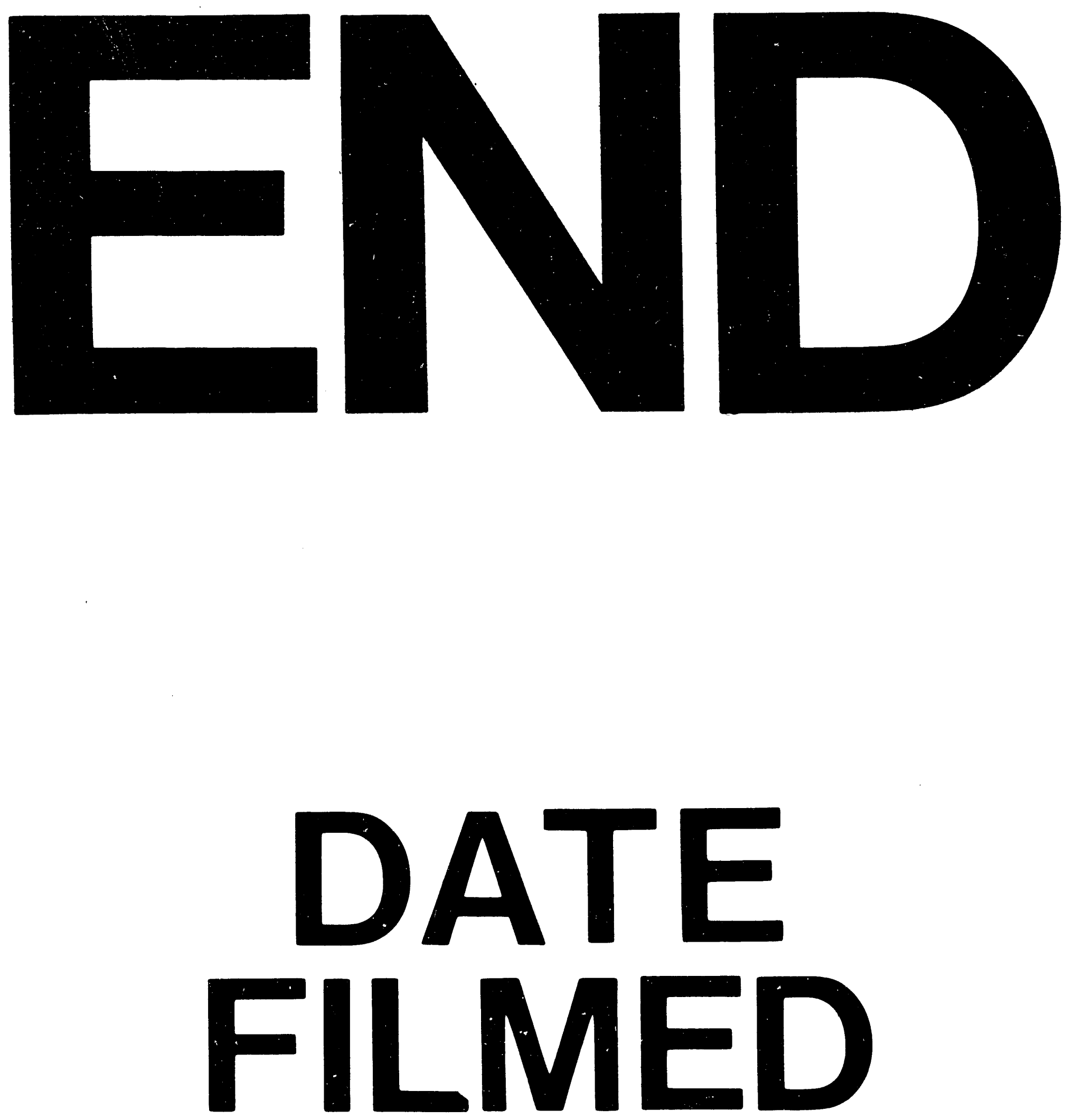

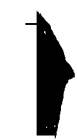

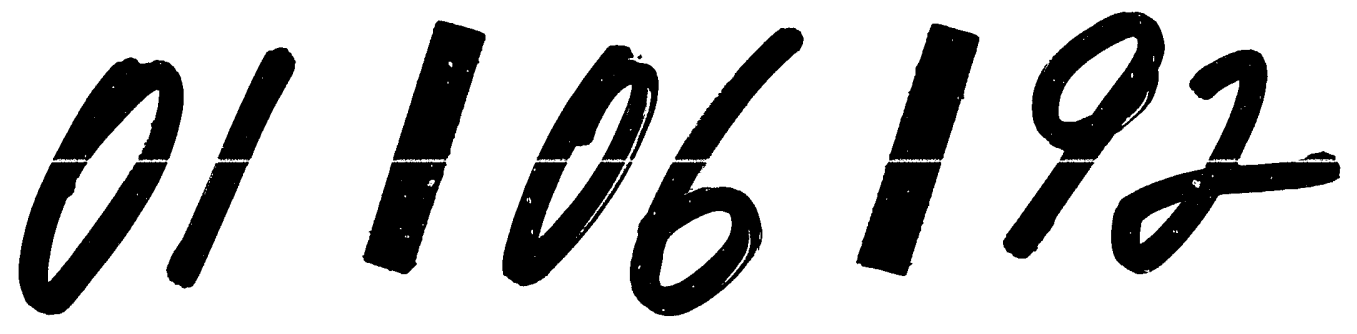


